\title{
ACTIVITY OF THE RUSSIAN MAIN CHOIRS' SINGERS AS THE COURT SERVICE CLASS PEOPLE IN $16^{\mathrm{TH}}-17^{\mathrm{TH}}$ CENTURIES
}

\author{
N. P. Parfentiev, parfentevnp@susu.ru \\ South Ural State University, Chelyabinsk, Russian Federation
}

In Moscow of the $16^{\text {th }}-17^{\text {th }}$ centuries there were two closely related centers of professional musical art. They were the choir at the Tsar's court and the choir at the court of the metropolitan (since 1589 - patriarch) of Moscow and all Russia, which united the best creative powers of the country. According to the author, the study of historical data on the life and activities of the Tsar's and patriarchal singers indicates that they belonged to the category of court service class people. Directions of their activities have often expanded. This was determined not only by the fact that the singers were literate, and sometimes had a high level of education, but also by the lack of a clear differentiation of services in the developing state apparatus, which made it possible to use the singers in various services - from file clerk to military. The findings are based on an analysis of a wide range of diverse archival documents and other sources. The obtained results allow us to clarify the social status of masters, who are often referred to the clergy class by researchers.

Keywords: Tsar's singing diaki, patriarch's singers, court service class people, professional activity.

The legal status, most types of salary in one or another combination (manor, monetary and natural products payments), the system of salaries of the Tsar's and patriarchal choirs' singers - all this was typical of those different categories that the service class people of the Russian state in the $16^{\text {th }}-17^{\text {th }}$ centuries belonged to [21]. For example,with the entry (transition) of even representatives of nobility into singing diaki their position did not changed and when they were assigned salaries, their estates and peasants were preserved [see: $4 ; 21]$. Consequently, their activities as the court Tsar's and patriarchal choristers were considered as one of the types of state service, which has its own specific features. The purpose of this research is to examine in detail the main directions of this activity.

The "major" 1 st and 2nd stanitsas of choirs, which consisted of masters of the highest class, upon demand of the Church Statute as usual stood on the right and left kliroses (choirs, parts of a church) ${ }^{1}$. Diaki and podiaki of other stanitsas took their places, including kliroses, in accordance with the part of the service and the chant performed at the time.

The sources have brought to us numerous detailed records of the way how the Russian court singers performed in the cathedrals of the $16^{\text {th }}-17^{\text {th }}$ centuries $^{2}$. On January, 21, 1526 during the wedding ceremony of Ivan the Terrible's parents, the Grand Duke Vasily and Elena Glinskaya, the "singing diaki on both kliroses were chanting Mnogoletie (expression of wishes for long life)" [18, p. 87]. The record of Ivan the Terrible's enthronement ceremony (16 January 1547) stated that "on the right kliros diaki sing Mnogoletie to the Grand Duke, and on the left kliros diaki also sing Mnogoletie" [8, v.1, p. 47]. The Assumption Cathedral "Chinovnik" of $1621-22$ repeatedly mentions the patriarchal diaki's

${ }^{1}$ In documents of the $17^{\text {th }}$ century, the $1^{\text {st }}$ stanitsas of the patriarchal and Tsar's choirs often referred to as the right, the $2^{\text {nd }}-$ as the left kliroses [28, № 64, fol. 212; № 67, fol. 275 ; etc.].

${ }^{2}$ A significant part of the information about patriarchal choir in the $17^{\text {th }}$ century comes from the "Chinovniki" handwritten books describing the course of important church services. singing "on both kliroses" or "by kliroses" [46, p. 27, $31,95]$. The fact, that during the services "the patriarchal chanters were singing on both choirs" is also mentioned in the "Chinovnik", compiled by a famous chant master Fedor Konstantinov in 1666-1674 [8, v. 5, p. 104, 115, 136]. Certain chants were performed by the diaki of the major stanitsas "na skhode" (when they gathered together in the middle of the church). For example, on September, 1, 1667 during the service devoted to the beginning of the new year (on "Letoproshenie") in honour of the Tsar's family "the patriarchal chanting diaks sang Mnogoletie standing in the middle" [8, v. 5, p. 113]; on March, 7, 1668 the patriarchal diaks sang stichera "on both kliroses", and "the very last one was sung by both stanitsas in the middle of the church"; on Christmas of the same year "after the divine service Mnogoletie they did not sing on kliroses, but they put on a lamp-stand with a candle in the middle of the church and sang the troparion of the feast" $[8, \mathrm{v} .5$, p. 122, 138]; on April, 14, 1693 "the chanters sang 'Gospodi vozzvakh' and sticheras on kliroses", then they "started to sing the last sticheron in the middle of the church" [10, p. 48].

Often during special solemn services the Tsar's and the patriarchal diaki sang together. As a rule, it happened on those days, when the Tsar visited the Assumption Cathedral in the Kremlin where the patriarch himself held the service. On such occasions the Tsar's diaki were singing on the right choir, the patriarchal diaki - on the left one. So, during the ceremony of the Filaret Romanov's enthronement as patriarch (June of 1619) "Mnogoletie" to the Tsar was performed on the right kliros by "the Tsar's chanters", and to "the new declared patriarch" - by the patriarchal diaki on the left kliros [8, v. 2, p. 220]; on September, 1, 1621 during the New Year service "the Tsar's and the patriarchal singing diaki sang antifones by kliroses", on August, 15, on the Assumption of the Virgin Mary holiday "the Tsar's singing diaki sang on the right kliros, patriarchal ones sang on the left one" as well [46, p. 2, 73).

The sources depict service-singing functions of podiaki as very diversified. Similar to diaki, they sang on kliroses ("and podiaki, as usual, on kliros sing the introit Mnogoletie") or in the middle 


\section{Искусствоведение}

of the church, ("all singing diaki and podiaki sang Mnogoletie to the Tsar in the middle of the church"; "the canon was sung to Easter and in honour of Alexey, the man of the Lord, by singing diaki and patriarchal podiaki in the middle of the church") [46, p. $184 ; 10$, p. 16;8, v. 5, p. 124]. Besides, depending on the position and role of chanting in the service, podiaki had to sing on the amvon ("podiaki sing the praise and the hymn "svetilen" on the ambon"), behind the altar ("minor podiaki sing "Ispolaeti despota" behind the altar"), before the holy gates of the cathedral ("and the praise is sung by podiaki before the holy gates") [46, p. 24,$74 ; 10$, p. $41 ; 34$, fol. 301; 6, fol. 34]. Podiaki knew the functions of a professional singer at a service very well, and, most probably, knew the full chant repertoire. When, due to some reason, singing diaki were absent, they could be easily replaced by podiaki ("and during the vespers service and matins there were no singing diaki, there were podiaki") [6, fol. 82-83].

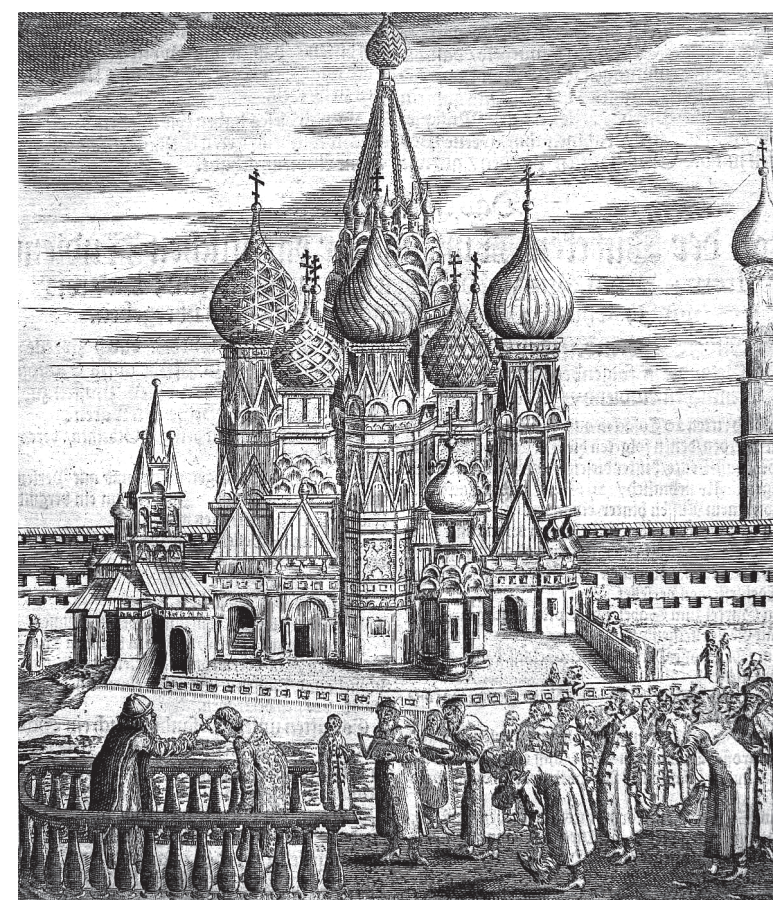

Divine Service at the Lobnoe mesto in Moscow. Engraving of the $17^{\text {th }}$ century

After some services there were walks to town, where chanters had to sing while walking. For example, in the "Chinovniks" of the first half of the $17^{\text {th }}$ century one can find the following: during the procession to the river for blessing the water on the holiday of Epiphany of Christ (January, 5) "singing diaki sing heirmoses... And having arrived to the water... they sing stichera 'The voice of the Lord above the waters', and while returning back from the water, patriarchal diaki sing"; on the day of Elijah the Prophet (July, 20), also taking part in the procession, "singing diaki, while walking, sing before the icon till the Lobnoye mesto (on the Red Square) and there podiaki sing", then on the way back to the Cathedral - singing diaki $[46$, p. $175,65,145 ; 39$, v. 3 , p. 50$]$.

Often professional singers of the $16^{\text {th }}-17^{\text {th }}$ centuries, in addition to the usual cathedral services, accompanied special events and ceremonies. In Moscow the heads of the state and the church took part in "The Donkey Walk" - the procession during the "Floriferous week", or on Palm Sunday ("The Entrance of the Lord into Jerusalem"). Among others there were also present the singing diaki of the Tsar's and patriarchal choirs. There exist numerous descriptions of processions, which took place in different years of the $17^{\text {th }}$ century $[6$, fol. $5-7 ; 8$, v. 5 , p. $122 ; 16$, p. $61-84 ; 46$, p. $105-$ 106]. The walk started from the Assumption Cathedral in the Kremlin: "first came podiaki in surplices, with the pussy-willow", which was decorated ("there were vegetables: apples and berries, raisins and wine grapes and nuts") and was put up on a decorated sledge ${ }^{1}$. During the procession to the Lobnoye mesto "singing diaki, both from the Tsar's and the patriarchal choirs, sing heirmoses in lines"; from the Lobnoye mesto to the Cathedral "the Tsar walks the horse under the patriarch", and "podiaki of the major and minor stanitsas walk before the great Tsar and the most holy patriarch and sing verse from evangelical sticheras..., and the most holy patriarch's singing diaki of the right and left kliroses walk behind and sing by turns verses from evangelical sticheras". Meanwhile, the "bishop's diaki of minor stanitsas are being sent forward by pairs with six small willows and sing evangelical sticheras until the most holy patriarch passes by on horseback" (according to some sources they were sent to the Spassky bridge) ${ }^{2}$. In the Cathedral the patriarch gave out branches of the decorated willow to all the "officials" and chanters. Thus, the procession was largely accompanied by chanting and presupposed active participation of the Tsar's and the patriarchal singers in it.

The following dramatized performance - liturgy drama "Peshnoe deistvo" (The fiery furnace action) was meant mainly for the patriarchal choir. In the capital city this ceremony took place in the Assumption Cathedral, where the day before a "pesch" (furnace) was put up on the place of the amvon. Before the beginning of the performance "the authorities" gathered together in the Krestovaya chamber, where three "youths", chosen from the young podiaki and specially trained by "the teacher of youths", as well as two "khaldeys" (servants of the Babylonian king Nebuchadnezzar) were present. All of them were going towards the Assumption Cathedral. The Tsar was also present there. On entering the "furnace" the youths started to sing "pripely" (a genre of chanting), while the right and left kliroses alternated in singing "zapevy"3. Khaldeys who lit up candles walked around the furnace and "threw inflamed grass" from

\footnotetext{
${ }^{1}$ In his notes, Fedor Konstantinov noted the special arrangement of willow in 1668: "Now it is green, it would have blossomed ... the fruits are seen ... and the apples are big and medium ... and near the willow the railing has been fixed ... and six good horses are harnessed into the carriage" $[8$, v. 5, p. 122$]$.

${ }^{2}$ On the path of the procession stood up to a hundred "guys", sons and nephews of streltsy and "Prikaz" "s (departaments) people, who paved the way with cloth, wich was given to them after the action [31, № 205, fol. 328; № 207, fol. 343; etc.].

${ }^{3}$ There are chants sang in "The Furnace action" in "Demestvennik" of the middle of $17^{\text {th }}$ century, written in the environment of the patriarchal singers [34, fol. 325-327].
} 
the tubes. After the singing performed by the youths was over, an image of an angel started to move down from the top of the furnace with great noise. Khaldeys prostrated themselves, and the youths were singing a verse "the Lord's Angel", and after that "the angel" was lifted up. Then the action was repeated. Khaldeys, having risen, expressed great amazement with what had happened. The youths were let out of the furnace unharmed. The stanitsas of minor podiaki sang "Slavoslovie" (the Gloria). Then the church service took place, after which the youths, while singing chants, escorted the patriarch from the church. On the same day, when the mass service was over, a table was laid at the patriarch's, where the youths, facing the patriarch till the third meals, were singing "Sticheras peschnye" (The Furnace act sticheras). Sometimes such table was laid at the Tsar's, like, for example, in the Golden Palace on December, 22, 1634 [42, p. 38]. So, all diaki and some podiaki of the patriarchal choir took part in "The Furnace act". As it was mentioned above, singing diaki as a result were granted clothes. All "peschnye otroki" (youths who took part in "Peschnoe deystvo") were given 7 altyn ( 0,21 rubles) each for "daily meals" and 5 altyn $(0,15$ rubles) each for high boots for the week during which they were getting prepared to play their roles, and after the performance they were given cloth in the value of 2 rubles; the podiaki of minor stanitsas for the Slavoslovie singing were given 0,08 rubles [16, p. $55-59]^{1}$.

The singers of the major Russian choirs of the $16^{\text {th }}-17^{\text {th }}$ centuries had to sing at various ceremonies, worked out for the most important events, connected with the Tsar's and the patriarch's courts life. These events were quite often of nationwide significance.

In the Grand Duke or the Tsar coronation ceremony, apparently, the most active part was assigned to the metropolitan (patriarchal) choir as the event was taking place in the Assumption Cathedral of the Moscow Kremlin. In the enthronement ceremony records (as regards Ivan III's grandson, Duke Dmitry's coronation (February 1498) and Ivan the Terrible's coronation (January 1547)) it is not specified which "diaki on kliroses sing Mnogoletie to the grand duke" [23, v. 12, p. $248 ; 8$, v. 1, p. 47]. The reference to the fact that "diaki sing Mnogoletie" is also present in the description of Fedor Ivanovich's coronation ceremony (May 1584) [26, № 96, fol. 4, 12]. The petitions of the Tsar’s singers of the 2nd stanitsa headed by Stepan Savvin and diak Ivan Fedorov "with partners" - of the 1st stanitsa of the Tsar's choir, who sang at the coronation ceremonies of Vasily Shuisky (1606) and Mikhail Romanov (1613), - state that the major stanitsas of the Tsar's and patriarchal choirs used to sing at the "Tsar enthronement ceremony" in the $17^{\text {th }}$ century for a reward [30, № 1148,

${ }^{1}$ Interesting details are provided by A. Olearius, who was in the 1630s in Russia. Khaldeys, allegedly having received permission of the Patriarch, ran around the city with fire and set fire to hay carts, beards of passers-by, etc. [17, p. 301]. However, Olearius took for the Khaldeys from "The Furnace action" of the "skomorokhs" (buffoons), mocking the church rites. For a detailed description of the action see: [10, p. $63-64]$.

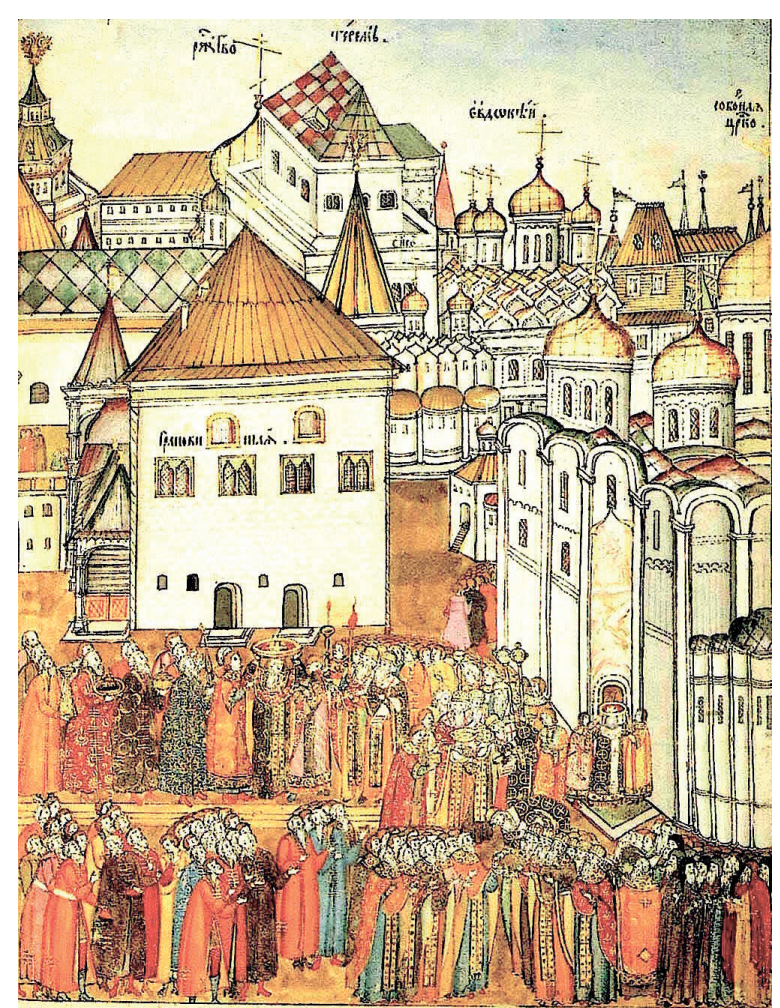

Coronation of the tsar

Miniature of the $17^{\text {th }}$ century. Fragment

fol. 1; № 36277, fol. 2; 43, p. 27]. At the ceremony of Fedor Alekseevich's coronation (June 1676) when the Tsar was entering the Cathedral, "Mnogoletie" was performed only by the patriarchal diaki, and then they "were singing Mnoga leta in demestvo" and other chants [18, p. 48-49].

At the Tsar's wedding ceremonies chanting was generally assigned to the Tsar's singers. In 1575 during Tsar Ivan's wedding ceremony diaki "on both kliroses sang Mnogoletstvo (same as Mnogoletie)" to the Tsar and to the Tsaritsa. In 1606 at False Dmitriy's wedding diaki sang "Mnogoletie three times" [26, № 5, fol. 9; № 6, fol. 5]. In 1626 “at the Tsar's delightful event, the wedding" of Mikhail Fedorovich, the major stanitsas of the Tsar's choir sang in lines [30, № 1148, fol. 1]. While the Tsar was in the bathhouse, the court people "till night" played the musical instruments $[9, \mathrm{v} .1$, p. 779-780]. Aleksey Mikhailovich turned away that tradition and ordered "his Tsar's singing diaki of all stanitsas to sing, in turns, line and demestvennye great sticheras from Feasts and Triodions" on the wedding day on January, 16, 1648 [11, p. 251].

There is plenty of information about the diaki singing during baptismal services for the newborn Tsareviches and Tsarevnas. As a rule, the Tsar's and the patriarchal singing diaki of the first stanitsas took part in these ceremonies (as well as krestovye diaki, who will be mentioned below $)^{2}$. Finally, both the Tsar's and

${ }^{2}$ Then they received cloth worth up to 5 rubles and money up to 4 rubles. So it was after the baptism of Tsarevna Irina in July 1627, Tsarevich Ivan Mikhailovich in June 1633, Tsarevich Dmitry Alekseevich in October 1648, Tsarevna Evdokia in March 1650, etc. [30, № 4095, fol. 1-4; 31, № 88 , fol. $140-143$; № 267 , fol. 211 ; № 282 , fol. 371 ; № 288 , fol. 607 etc.). 


\section{Искусствоведение}

the patriarchal singing diaki had to sing at the funeral ceremony of the Tsar's family members and their immediate relatives. For example, on May, 20, 1668 a requiem service for Tsaritsa Maria Ilyinichna's father "was performed by the Tsar's singing diaki of all stanitsas and the patriarchal singing diaki"; on March, 3, 1669 at the Tsaritsa's burial both major choirs of the country "walked and sang the threnody" [8, v. 5, p. 127; 30, № 52009, fol. 3].

To the group of rites, connected with the most important events, ascending to the metropolitan (patriarchal) choir, we will, in the first instance, refer the nomination and enthronement ceremony of the head of the Russian Church. In February 1539 at the ceremony of exaltation of the All-Russian Metropolitan Ioasaf both stanitsas of the metropolitan diaki sang. And when Ioasaf bestrode a "donkey" (horse) and went away from the Cathedral (in that case without a willow) to the court of the grand duke, the grand duke's and the metropolitan singing diaki walked before him, singing verses. The same happened on his way back to the Cathedral [3, p. 158 - 160]. In the days of the enthronement ceremony of the first patriarch Iov (January 1589) the leading role in the music and chant accompaniment of the rite was assigned to the patriarchal choir, specifically to the singing diaki of both stanitsas. The latter sang not only in the Cathedral. During the solemn "Donkey walk" "before patriarch Iov, walking around the town, his diaki sang selected sticheras of the Lord's and the great saints' feasts"; then "Mnogoletie" was performed in the patriarch's chambers, and "at the table" — "slavniki"(doxastikons). Upon a special demand podiaki also sang "at the table". On the last day of the rite another walk of the patriarch took place "on a donkey" (horse), led by the boyar and the future Tsar Boris Godunov, "and both singing diaki and podiaki sang verses near the towns" [39, v. 5, p. 316-327]. In the enthronement ceremony of patriarch Filaret Romanov "the Tsar's singers" were played significant role in chanting as well. The day before the second stanitsa of the Tsar's and both stanitsas of the patriarchal diaki were sent to Mozhaisk to meet Filaret. Then during the ceremony the Tsar's diaki sang on the right kliros, the patriarchal diaki - on the left one. Probably, they also took part in "The Donkey Walk around the town" [31, № 204, fol. $654-655$; 8, v. 2, p. $213-221]^{1}$. Documents on the following patriarchs' enthronement also mention that the patriarchal and two major stanitsas of the Tsar's singing diaki "were singing during the ceremony" and "while walking around the towns", for what they were given cloth and money [30, № 3419, fol. 1; 28, № 15, fol. 150; № 60, fol. 188]. In the descriptions of rites of the second half of the $17^{\text {th }}$ century the Tsar's diaki are not mentioned, but chanting, performed by the patriarchal diaki and podiaki, is described in details. Apparently, the rite itself was somewhat changed: for example, in the town the patriarchs used to ride in sledges or carriages ("diaki and podiaki walked before the carriage and sang doxasticons") [8, v. 6 , p. $237-239$; v. 5 , p. 103,104$]$.

A significant amount of documents of the $17^{\text {th }}$ century have brought us information about chanters' singing

${ }^{1}$ Later, the singers of the Tsar's and the patriarchal choirs were granted cloth on behalf of Tsar Michail "for how to put his father on the Patriarchate" [31, № 204, fol. 723]. during the hierarch's ceremony of enthronement as well, for what they were given cloth used as an upholster for the "patriarch's seat" at every particular ceremony. Most frequently the "supply" of cloth in the value of 16-20 rubles was delivered to the patriarchal singing diaki [31, № 205, fol. 184, 202; № 206, fol. 213; № 280 , fol. 78$]$. The Tsar's diaki took part in those rites not so often. In 1616 along with the patriarchal diaki they were given cloth for singing at the Pskov archbishop's ceremony of enthronement; in June 1641 and April 1651 after the enthronement ceremony of the archbishops of Astrakhan and Ryazan-Murom the cloth was given to the first stanitsa of the Tsar's singers [31, № 201, fol. 148; № 296, fol. 242; № 306 , fol. 165]. Podiaki are also mentioned in these records. In August 1655 after the Suzdal archbishop's enthronement "supplies" of cloth in the value of 32 rubles were given to the patriarchal diaki and podiaki [31, № 309, fol. $129-130 ; 8$, v. 5, p. 150]. Sometimes the Father Superiors of major monasteries were ordained in the capital, rewarding the singers for their work in their own way [33, № 39, fol. 160-161].

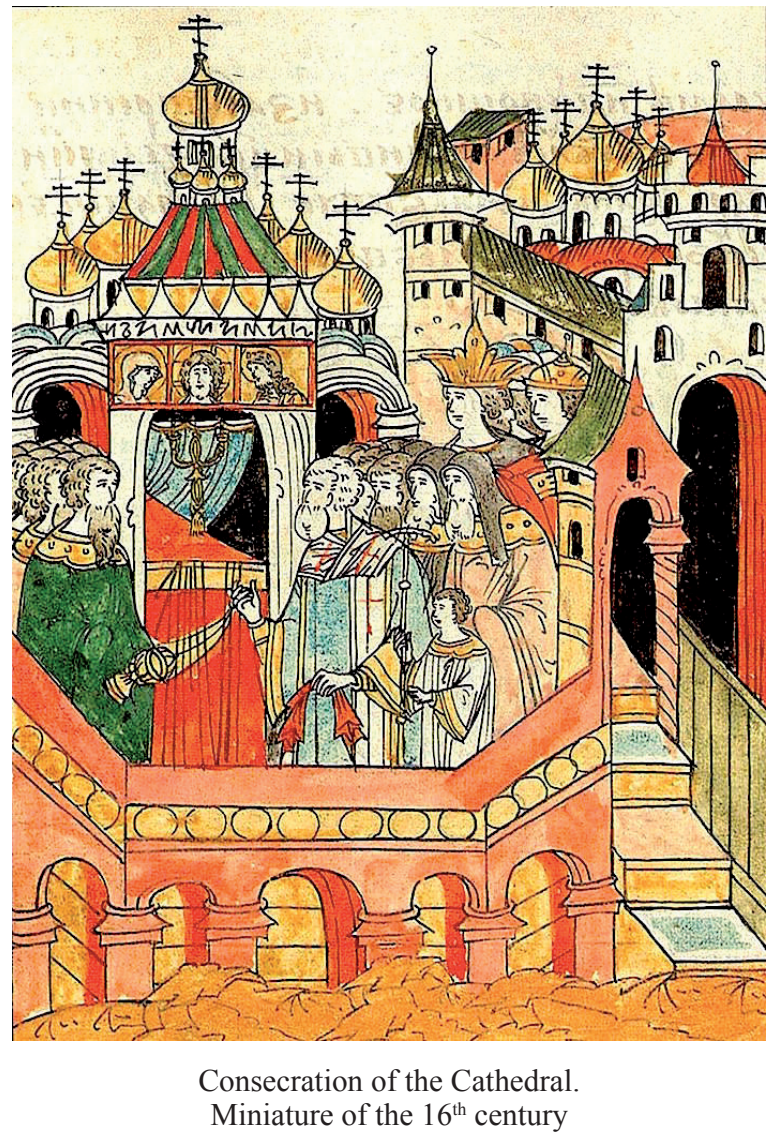

Among other rites, in which the chanters of Russia's major choirs sang there was the consecration ceremony of court churches. In November 1627 and in August 1636 the diaki of the $1^{\text {st }}$ and $2^{\text {nd }}$ stanitsas of the Tsar's choir were granted 5 arshins $(0,71 \mathrm{~m})$ of taffeta each for singing during the consecration ceremony of the Evdokia church in the Tsaritsa's court and the church of Christ "at the Tsar's court” [31, № 283, fol. 73, 93; № 291, fol. 388, 400, 403]. The funeral ceremony of deceased patriarchs was one more occasion when the whole patriarchal choir and major stanitsas of the 
Tsar's singing diaki were present. For reading the Psalter and for singing chants in the cathedral or "in the course of carrying out" the chanters received straight "from the Tsar's hands" the amount of money assigned to a particular stanitsa ${ }^{1}$.

During numerous trips with the Tsar's family members and the patriarchs around the towns, monasteries, churches, Palace settlements etc, singers continued to execute their singing functions. While on a visit to Novgorod with Ivan the Terrible on 23 July 1571, during icon processions, "Moscow singing diaki sang many various sticheras" and canons, and then in the Holy Wisdom Cathedral they "sang Bogorodichny (hymns in praise of the Virgin Mary)" [23, v. 3, p. 165]. In March 1655 for singing in the settlement Bratoshino, where the patriarch stayed for some time while on "a trip" to the Holy Trinity-St. Sergius Monastery, the singing diaki Fedor Konstantinov and Nester Ivanov were rewarded in particular [28, № 38, fol. 143]. In September 1668 the Tsar family and the patriarch visited the Holy Trinity-St. Sergius monastery, where the escorting singing diaki sang, and on their way back in the patriarch's "home settlement" Pushkino "singing diaki performed the Mass" [8, v. 5, p. 136, and also: fol. 120, 125 etc.]. Singers frequently went on trips to take part in a funeral service for a deceased patriarch. So, in May 1687 the patriarch granted 2 rubles "to both kliroses" of his diaki and podiaki, who stayed with him in the Holy Trinity church in Mozhaisk and sang at the funeral service for his father P. I. Savelov [28, № 122, fol. 178-179].

Thus, professional singing functions of the Tsar's and the patriarchal choirs, basically, were implemented in divine services and rites in churches (cathedrals). However singers of those choirs quite frequently took part in non-liturgical, secular as well as public and political ceremonies.

On the occasion of grand delegations or embassies' arrival in Moscow, at coronation ceremonies, exaltation to the patriarchate ceremonies, in connection with baptismal ceremonies and the name-day celebrations of the Tsar's family members, on some particular holidays, memorial days, as well as on other occasions solemn receptions and dinner parties ("stoly") were held in the Tsar's palace chambers or in the patriarch's palace chambers ("khoromy"). On September, 14, 1557 in the Tsar's Obedennaya palata (Dining chamber) there was a reception with the foreigners present. An Englishman, when describing that event, noted in his memoirs: "During the dinner 6 singers came in and stood in the middle of the hall, facing the Tsar, they sang three times". But their songs and voices slightly delighted or did not appeal to the foreigners, who were brought up on different music traditions [41, p. 14]. On one of the days of his exaltation ceremony the first Russian patriarch Iov, on January, 27, 1589, was visited by patriarch Jeremiah of Constantinople. When everyone stood up from their "assigned" seats, the 1st stanitsa of the Russian patriarchal choir, Ivan Makariev with his partners, "began

${ }^{1}$ The tsar's and patriarchal diaki of the $1^{\text {st }}$ and $2^{\text {nd }}$ stanitsas were given 1.5 rubles per stanitsa, for the rest ones from 0.5 to 0.15 rubles. All of them were later given several times large sums in memory of the deceased patriarch [28, № 12 , fol. 602 ; № 75 , fol. 534 etc.; № 78 , fol. $431-434$; etc.]. to sing Mnogoletie to the Tsar", after "wishing good health" the 2nd stanitsa headed by Pervy Fedorov sang Mnogoletie and "Ispolaeti" to patriarch Jeremiah, then the diaki of the 1st stanitsa "started to sing" Mnogoletie and "Ispolaeti despota" to the new patriarch Iov. On the same day a table was laid in the Bolshaya (Big) chamber where both stanitsas of the Russian patriarchal diaki sang Assumption chants of praise, and then "after consulting each other, the patriarchs told the patriarchal singers, Dmitry with his partners, to sing in Greek"; later all podiaki also sang "as they were supposed to" [39, v. 2, p. 319-320, 322 - 323]. As a rule, the dinner was ending with "Grace cups", which represented special church and secular rites, which had been popular in Russia since the $11^{\text {th }}$ century and stood at the origin of the Russian panegyric choral music [5, p. 204-214]. In the Big chamber of patriarch Iov the first cup was in honour of the Holy Mother and the Moscow miracle worker Peter, and "the verses to be sung were doxasticons of the first mode (Epiphany) and then - the sovereign cup to the Tsar and the grand duke Fedor Ivanovich... and the patriarchs ordered to sing the verse: Lord, help gentle David... and the large Mnogoletie; and the cup of the sovereign's lady - the Tsaritsa Irina, and the verse that was sung was a doxasticon of the sixth mode: Our Saviour Tsaritsa, stand on right to our Saviour... and Mnogoletie; and after that cup - the cup of Iov, the patriarch of Moscow and all Russia, and the cup of Jeremiah, the ecumenical patriarch" [39, v. 2, p. 323].

There exist numerous references of the Tsar's and the patriarchal choirs' singing "at the table" or "before the table" in the $17^{\text {th }}$ century sources. Thus, to celebrate Easter the table was usually laid at the Tsar's in the Palace of Facets, on the following days of the week, - at the patriarch's in the Krestovaya chamber. The head of the state and the head of the church were both present. According to the records that have reached us from the first half of the $17^{\text {th }}$ century, when the "meal" was over, podiaki sang "Christ is risen" three times, the ninth chant of canon and doxastikons "Before morning" and "When laying to rest" $[6$, fol. 39; 39, v. 3, p. 131; 46, p. 129]. Records of the second half of the $17^{\text {th }}$ century state that on Easter the patriarchal singing diaki and podiaki "sang Easter canon of the Bible at the table" [8, v. 5, p. 123-124]. On the holiday of Assumption (August, 15) the table was laid in the patriarch's Krestovaya chamber, where "the Tsar ate bread at the table" and where "the patriarchal singing diaki sang at the table", and after the meals - to the cup of the Mother of God [8, v. 5, p. 133]. On "Letoproshenie" (September, 1) in the Tsar's Palace of Facets "the Tsar's singing diaki, the first stanitsa, sang at the table: "Let the Tsar live forever; and then patriarchal singing diaki sang" [8, v. 5, p. 113].

There are some more examples. In November 1666 on the Ecumenical patriarchs' arrival in Moscow the Tsar also hosted the receptions (in the Palace of Facets or Stolovaya (Dining) chamber, or in the Tsar's "room"), after which there were "cups of the Holy Mother and the Tsar" or only "the Tsar's cup". "And singing diaki and podiaki sang at the table and to the cups of patriarchs" [8, v. 5, p. 99-100, 104 etc.]. After the elevation of patriarch Ioasaf (February 1667) the tables were laid in the patriarch's Krestovaya chamber as well, where singing 


\section{Искусствоведение}

diaki performed "the Tsar's cup, and after that — the cup of all the three most holy patriarchs" (including the "Ecumenical"), "great Mnogoletie to the Tsar and "Mnoga leta' to the patriarchs three times" $[8$, v. 5, p. 128]. Thus, singing "at the table" was obligatory, and if it, due to some reason, did not happen, which occurred quite rarely, then the writers in their records of the rites noted: "No sticheras were sung at the table" $[8$, v. 5, p. 103].

There exist peculiar references of individual chanters' singing before the Tsar. For example, in 1651 the patriarchal singing diak Fedor Kozmin was given "hanburskoe" (from Hamburg) cloth in the value of 2 rubles for singing "The doxastikon to Aleksey, the man of God before the Tsar in the Dining chamber on March, 17' [31, № 306, fol. 145]. The Tsar's singing diaki Vladimir Golutvinets and Rodion Grigoriev on January, 3, 1675 in the Tsar's presence were given 6 and 2 rubles respectively "for the stichera ' $O$ divnoe chudo' ('Oh wonderful miracle') which they sang in presence of him, the great Tsar, in the front room" [ 39 , v. 23 , p. 354]

Other cases of non-liturgical singing of the central choirs include singing during solemn walks, processions, high officials' meetings.

The sources mention this fact, for example, in the records of Tsar Aleksey Mikhailovich's returning from "the Lithuanian campaign" in 1655, when among the welcoming people "before the Tsar's Majesty many children in white garments walked, who held sheets of paper in their hands for while singing" and in the records of the Tsar's marching out to the fields against the Swedish king on May, 15, 1656, when the patriarch took part in the procession, and his singing diaki and podiaki, "while walking, sang various sticheras in red surplice till they came to the Lobnoye place" [26, № 141, fol. 12; 10, p. 18]. On February, 3, 1664 on his way to the troops review Tsar Aleksey Mikhailovich was watching his armed forces in Semenovskoe and at Devichje field... for his march off against the Polish king", among the escorting people there were the Tsar's singing diaki who walked singing [16, p. 1229-1237]. Singers also took part in the ceremonies of troops send-off led by voivods or in the see-off ceremonies of important ambassadors. In 1659 the Tsar's diaki (except for the 3rd stanitsa) sent off and then greeted back the troops of the boyar Y. A. Dolgorukov and "Swedish embassy campaign” of the boyar I. S. Prozorovsky [30, № 6389, fol. 1-2]. In May 1668 the Tsar and the patriarch took part in the send-off ceremony of duke G. S. Kurakin's army and the embassy campaign of A. L. Naschekin "to the Polish land" and "on their way the Tsar's singing diaki sang the verses before the icon of the Saviour" $[8$, v. 5, p. 128].

Sometimes the icon accompanying the troops in military campaigns was left in a foreign land after a lost battle. A solemn ceremony with both choirs singing was arranged for its return. On October, 16, 1667 the icon of the Holy Mother which had accompanied I. A. Hovansky's army and was left in "the Polish land" was delivered to Moscow. When the icon was being taken out from the carriage in the presence of the state rulers the patriarchal singing diaki began to sing and sang while "walking to the monastery"; when the icon was being carried to the Assumption Cathedral, the
Tsar's singing diaki sang "the Greek canon to the Assumption" on their way to the Lobnoye place, and then the patriarch's chanters" sang "the Greek canon "Water was crossed' till they arrived at the Cathedral" [8, v. 5, p. 116-117].

In the $17^{\text {th }}$ century documents there are numerous records of the patriarch's appearances at solemn services in the Assumption Cathedral. Before the Easter service in the presence of the "authorities" the patriarch walks to the Golden or Dining chambers to the Tsar. Podiaki, walking before him, are singing "Christ is risen" ("Christos voskrese") three times and chants from the Easter canon, and having come to the Golden Chamber, they will sing again. Then the patriarch goes to the Cathedral, "podiaki are walking before him with candles and sing the verse: 'Your Resurrection' ('Voskresenie tvoe')" [6, fol. 32; 39, v. 3, p. 127, 130; 46, p. 129]. Singers also escorted the patriarch at the processions after solemn services and official dinners. Escorting the Ecumenical patriarchs' appearances as well as trips escorting were often carried out by the Tsar's choir singers. On November, 4, 1666 from the town residence of Kirillov monastery the patriarch of Alexandria Paisius and the patriarch of Antioch Macarius visited the Faceted Chamber to see the Tsar, and "first their elders were walking, and the Tsar's singing diaki were singing before them"; after the dinner "the patriarchs went away to the town residence, and "the Tsar's singing diaki sang before them". On June, 5, 1668 patriarch Macarius was "driving in his carriage" to see the Tsar, "the Tsar's singing diaki sang before him, and on his return from the Tsar they sang as well" $[8$, v. 5, p. 98-99, 128]. Sometimes these functions were performed by the chanters of Russia's two major choirs $[8$, v. 5, p. 143$]$.

One of the chants performed during non-liturgical rites was the annual "slavlenie" (praise) of Christ on Christmas (according to some sources - on Easter as well). All the singers of the Tsar's and the patriarchal choirs, for example, on December, 25, 1667 "at the vesper service praised the Lord at the Tsar's chamber and in the front Chamber". In the following year "the Tsar's choir praised the Lord on the holiday after the vesper service in the inner porch before the Front chamber, and then the whole Tsar's choir drank mead - a reward from the Tsar - in the inner porch before the Front chamber, it was boyar Bogdan Matveevich Hitrovo's treat. On the same day, at the vesper service, having praised the Lord at the Tsar, they went... to the patriarch of Moscow Ioasaf to praise the Lord, and to patriarch Paisius they went in the morning of Saturday, December, 26. The money was the same" $[8, \text { v. } 5, \text { p. } 119,138]^{1}$

The Tsar's and the patriarchal choirs praised the Lord not only in the Tsar's and the patriarch's chambers. They traveled to boyars' and dukes' chambers, hierarchs and monastery town residences, to the courts of Prikaz (departmental) diaki and everywhere they were given "slavlenoe" payment; from the Tsar's and the patri-

Usually the choristers praise of Christ is with the tsar in the "Dining Room". Almost annual references to the time of Tsars Mikhail, Alexei, Fedor have been preserved about this. $[42$, p. $57,88,108,134,147$ etc. $]$. 
arch's stables they were given horses ${ }^{1}$. On December, 27, 1585 singing diaki visited the Chudov monastery, where after the song of praise each major stanitsa of the Tsar's singing diaki was granted 0,5 rubles, the $3^{\text {rd }}$ and $4^{\text {th }}$ stanitsas - 0,25 rubles each etc. [27, № 273, fol. 121-122]. In 1605-1608 in the town residence of St. Joseph Volokolamsk Monastery every year the Tsar's and the patriarch's singers were paid an equal amount of "slavlenoe", from 0,25 rubles (first stanitsas) to 5 dengas (minor stanitsas), and in the following years - a little less $[33$, № 15 , fol. 54; № 19, fol. 158; № 32, fol. 62; № 39, fol. 161; etc.]. In 1677 an unprecedented event occurred: many of the Prikaz diaki refused to let the Tsar's singers inside their homes to sing praise. In response to that "folly" the Tsar forbade the Prikaz diaki to take money from petitioners for "compliments and offerings" (payoffs) on penalty of punishment. Since then there were no more incidents like that $[25$, p. $64-65]$.

The professional functions of chanters were not confined to singing only. Their duties included numerous "non-singing" functions, especially for the Tsar's singing diaki of minor stanitsas and the patriarch's podiaki. The latter, for example, had to provide everything necessary from the patriarch's Riznitsa (vestry) for those Moscow churches where the patriarch was to hold a service on some holiday or other event. There were many such events during the year, so some podiaki had to perform those assignments more than once. The singers were given money from the treasury "for the cab". So, in May 1634 and May 1635 the podiak Fedor Konstantinov was given money "to carry" vestry, carpets, surplices and icon lamps "that he had taken from Riznitsa" to the side altar of martyr Irina of St. Nicholay church, "situated in the corner of the town wall", when the patriarch "went there to praise the angel of Tsaritsa" [16, p. 361, 367, 371 etc.). Apart from that, singers performed other assignments in organization of cathedral services. During the services singers also performed a number of duties, not connected with singing. In the $17^{\text {th }}$ century "Chinovniks" it is often mentioned, that podiaki "lay the carpet and the mat with image of eagle ("orlets") in the middle of the church", where the patriarch stood. Sometimes podiaki "put only the carpet and a chair with a pillow, and do not arrange a patriarch's place"; at the appearance of the patriarch for the service he was also escorted by podiaki "with candles"; at services they had to do the readings, help the patriarch with the crosier, books, etc. [46, p. 6, 27, 34 etc.; 10, p. 40, 55 etc.). During the funeral ceremonies for the members of the Tsar's family all the singers of the central choirs had to read the Psalter in turns in the Chambers of the Palace and in the Archangelsky Cathedral, where the funeral was taking place [31, № 1076, fol. 74-76; 30, № 16770, fol. 1-4; 39, v. 23, p. $54-57 ; 16$, p. $1272-1273]$. In the second half of the $17^{\text {th }}$ century a new order was established, according to which on Christmas and Easter young singers had to deliver a "holiday speech and greetings" or an "oration” [28, № 89, fol. 296; № 92, fol. 248, 249; № 108, fol. 190; 30, № 19126, fol. 10) ${ }^{2}$.

${ }^{1}$ Since 1676, the patriarch ordered instead of horses to give his choristers three rubles for the cabmen [28, № 89, fol. 213; № 92, fol. 249].

${ }^{2}$ In the second half of the 80 s and early 90 s. Karion, the editorial clerk of the Publishing House, taught the podiaks to the "orations" [28, № 127, fol. 185; № 129, fol. 183; etc.].
Among the functions, not connected with singing, singers had to escort the Tsars and the patriarchs (among other court people, e.g. boyars, noblemen etc.) in their trips, which were most commonly taken to the ancient sacred places of Russian cities and monasteries as well as to the Courts' settlements. In 1654 and 1655 patriarch Nikon made "journeys" to settlement owned by the patriarch's court Vladykino, the Holy Trinity-St. Sergius monastery, Kalyazin, Vyazma, Klin, Tver and other cities and settlements. Most frequently Nikon visited "new" monasteries built by him, like in 1657 - New Jerusalem Monastery. Everywhere he was followed by his singing diaki and podiaki [28, № 36 , fol. 343; № 38, fol. 145, 583; № 43, fol. 231]. In January 1668 , when the Ecumenical patriarchs during their stay in Russia decided to visit the Savvo-Storozhevsky monastery in Zvenigorod, among the escorting people there was the $2^{\text {nd }}$ stanitsa of the patriarch's singing diaki, a subdeacon, the major and the minor stanitsa of podiaki; in April of that year the same singers of the patriarchal choir visited the Holy Trinity-St. Sergius monastery together with the Eecumenical patriarchs [8, v. 5, p. 120, 126]. In December 1672 a special stanitsa of the Tsar's diaki from Novgorod was given 3 rubles each instead of slavlenoe for staying with the Tsar during the ceremony of praising the Lord in the Tsar's Kolomenskoe estate [39, v. 23, p. 104]. In 1677 all the Tsar's singers were given out fur coats for escorting the Tsar during his Kashin town journey [30, № 16595, fol. 8]. In the beginning of the $1680-\mathrm{s}$ in Preobrazhenskoe settlement the "front chambers where singing diaki would stand for the Tsar's arrival” [31, № 1032, fol. 33] were under construction. There is a detailed description of one of the trips of Tsar Fedor Alekseevich on September, 21, 1680 to the Holy Trinity-St. Sergius monastery. While the Tsar was saying prayers in the Assumption Cathedral, where the patriarch's singers sang "in demestvo", the conductor Pavel Mikhailov was leaving the Palace through the Savior's gate. He was followed by the Tsar's singers in "Greek" garments on horseback by three in a row, then there came "krestovyi vozok" (cart with liturgy accessories), and after him there were chanters again with Osip Sedoy and his partners, by two in a row. Behind them there was a carriage with the Tsar's confessor and priests accompanied by three singing diaki on horseback, followed by the court people (solicitors, stolniki, etc.) and a detachment of streltsy (military corps) [9, v. 2, p. 179]. In 1683-84 all singers, including a senior choir singer, accompanied the Tsar's family in "Trinity and Kolyazin trips" [36, fol. 95, 106; 40, p. 265]. As it was mentioned, from time to time singers were given a special travelling garments, they were also provided with everything necessary for riding ${ }^{3}$.

As one can see, the scope of professional functions that the singers of Russia's major choirs performed was pretty wide. But their general activity was much wider and diversified. All the duties they had to do (which can not be referred to their direct professional functions) can also be divided into those connected and not connected with the art of chanting.

${ }^{3}$ In June 1655, patriarchal singers "for hiking" were given money for saddles, bridles, etc. [28, № 38, fol. $164 ; 36$, fol. 37]. 


\section{Искусствоведение}

First of all, one should mention the most important activity in the life of the choir (as regards maintaining their professional level) — the process of educating young singers. It was assigned, as a rule, to the most experienced diaki or even podiaki who knew all the niceties of singing and who had skills in teaching. Interestingly enough that in records dated by 1617 we come across a reference: "little singing diaki were taught how to sing" by several people at once - a singer-"nizovschik" ("nizovschik", "demestvennik", "vershnik" - singers who specialized in singing of certain parts — "lines" of polyphonic chants) from the major stanitsa Ivan Fedorov and singer-"vershnik" Bogdan Kipelov as well as the second stanitsa's singervershnik Ivan Semionov and singer-demestvennik Postnik Stepanov ${ }^{1}$. That was probably connected with the fact, that at that time "line" polyphony just started to be widely included into the repertoire of choirs, therefore it required efforts of several masters to teach the young diaki, who "specialized" in singing of certain parts - "lines"; subsequently many singers of the central choirs had a good command of all vocal parts and the repertoire in full. Evidently, they were the ones assigned for teaching the art of singing. In February 1625 the Tsar's chanter Pyatiy Filatov was rewarded with damask and cloth for teaching the young singing diaki of the Tsar's choir and the patriarch's podiaki; in January 1628 the Tsar's chanter Ivan Fedorov and in July 1631 together with his partners Ivan Semenov and Yuri Fomin were granted the same for teaching only the Tsar's novice singers [30, № 1105, fol. 1; 31, № 283, fol. 154; № 286, fol. 350]. For some years a teacher of singing in the patriarchal choir was a diak of the 1st stanitsa of the same choir Bogdan Ivanov. In March 1647 the patriarch granted him 2 rubles "for his great work in teaching podiaki to sing"; on July, 2, 1651 money was also given for the improvement of the educational process by methods which were quite traditional for that time: he was instructed to buy "a lash to teach the youths" [16, p. 968; 28, № 28, fol. 467]. Since 1658 - 59 "minor" podiaki were taught by the podiak of the first stanitsa Savva Semenov who had been dismissed a year before that. He was assigned a salary of 5,5 rubles and was given 1 ruble "for food". Apparently, Savva proved to be a good specialist: since $1666-67$ his salary was increased to 10 rubles; according to the $17^{\text {th }}$ century records he got this salary up to 1669 [28, № 47, fol. 21, 319; № 51, fol. 18, 334; № 60, fol. 70]. After the reform in the sphere of the Russian church chanting art and the revision of books on "razdelnorechie" (an increase in liturgical vocalization in comparison with spoken language) in 1669-1671 [20, p. 128 - 139] young singers of the Tsar's choir were taught by "the masters of narechnoie chant" (pronunciation of poetical texts in correspondence with spoken language). In 1672/73 - 1674/75 with the "minor" stanitsas of the Tsar's choir the diak of the 1st stanitsa of the same choir Aleksey Nikiphorov worked as such master [28, № 78, fol. 173; № 81, fol. 207]. Since February 1672 by the Tsar's order the subdeacon of the Book-printing Department Ephim Bogdanov

${ }^{1}$ All masters were granted cloth in 1,5 rubles [31, № 203, fol. 106]. was told to "work as a master of narechnoie chant and to teach his, the Tsar's, new singing diaki, and to continue working in the Department of Book Printing [32, fol. 43]. In 1675/76 - 1676/77 Aleksey and Ephim were mentioned "in the staff" of the Tsar's choir, but in the "staff list" of those years they, as well as the chanter Faddei Nikitin, Subotin's son (who was famous in the second half of the $17^{\text {th }}$ century), were registered at the very end, after all singing diaki, which allows to suppose that at that time all three masters were engaged in teaching the narechnoe chanting only [30, № 17440 , fol. 16$]^{2}$. With the spread of Partesny style, the choirs' staff began to include special teachers for young singers. So, in 1695 "a teacher for minor podiaki" was employed in the patriarchal choir - Tikhon Semenov Ustyuzhanin. He was assigned a salary, equal to the salaries of the singing diaki of the 1 st stanitsa -12 rubles; in the staff list his name was written down first, before the diaki [28, № 160, fol. 109; № 165, fol. 9; etc.].

The assignment to teach young podiaki every year for them to play their roles during "The Furnace act" consisted, mainly, in learning the chants, which, as we have already noted, largely accompanied this rite. This assignment was also given to the most experienced singers of the patriarchal and, more rarely, of the Tsar's choir. In 1613, for example, the patriarchal singing diak Grigory Andreev became "the teacher of youths"; in 1618 this post was given to "a master of the Furnace act”, the patriarchal choir diak Sila Matveev [31, № 199, fol. 196; № 203, fol. 238]. In 1619-1621 the singing diak Yury Bukin was assigned to the Tsar's choir for teaching youths, but in 1622-1634 "youths were taught to sing for the Furnace act" by the patriarchal singing diak Andrei Kuzmin; in 1636-1641 — by the diak of the patriarchal choir Bogdan Ivanov, who later became a famous teacher of all minor podiaki [28, № 1, fol. 186; № 9, fol. 470; № 12, fol. 131, 455; 30, № 3033, fol. 10; 31, № 205, fol. 106; № 280, fol. 194; № 535, fol. 16; etc.]. "The teacher of youths" was usually granted 20 altyn ( 0.6 rubles) for firewood and candles for the week during which he had to teach the youthssingers; and when the rite was over, he was rewarded with cloth in the value of $2-2.5$ rubles, and sometimes more, and money in the amount of 2 rubles.

When necessary, singers of the main choirs taught the local chanters. After the establishment of Tobolsk eparchy in 1620 - 1624, the stanitsa of the archbishop's diaki and stanitsa of podiaki were taught to sing "threeline" chanting by the Tsar's choir diak Samoilo Evtikheev. The teachers of other Siberian singers were also singing diaki from the Tsar's choir - Ivan Ischeikin, Sergey Vasiliev and Vasily Kharitonov [31, № 207, fol. 283; № 209, fol. 598; № 283, fol. 314; etc.].

The singing diaki, who had been acknowledged masters of chanting, were entrusted to teach not only young singers, but also the Tsar's children. In October 1637 Tsar Mikhail assigned his choir's diak Luka Ivanov to "teach the Tsarevich, duke Aleksey Mikhailovich to sing Octoechoes", and in June 1638 the Tsarevich started to "learn strochnoe (line) chanting" under the direction of his teachers - the chanters Ivan Semionov

${ }^{2}$ A place has been left in the list in front of the names of these three masters, probably the subtitle of "The masters of narechnoe chanting" was missing here. 
and Mikhail Osipov [12, p. 612]. Later, having become the Tsar, Aleksey Mikhailovich excellently knew the art of Znamenny raspev (chant) and created his own chants. In the middle of the 1690 -s by a special personal order Tsar Peter entrusted the singing diak Nikifor Vyazemsky to teach Tsarevich Aleksey Petrovich grammar and singing. He became one of the Tsarevich's tutors (until 1718 ) and had to give regular reports on his educational progress [44, p. 297-298, 311 etc.].

The greatest importance in non-singing activities, though connected with the singing activities of diaki and podiaki of Russia's main choirs, was attached to writing ecclesiastic music books. Chant music books were stored in the Tsar's and the patriarch's special Chanter chambers, where chanters worked. In choirs those books were used during singing and teaching the art of chanting. The books were registered in the inventory. A part of them was located directly in the places of service - in Cathedrals. There is numerous documentary evidence of such writing activity of singing diaki and podiaki. The chanter of the Tsar choir Mikhail Osipov, for example, in March 1638 was granted damask and cloth for "his editing old books and singing" [31, № 293, fol. 172]. Mikhail Osipov served as a singing diak during the first half of the $17^{\text {th }}$ century. In the "Inventories of books" (1682) in the Tsar's library there exist records of chanting manuscripts, written by that master: "Sticheron from Gospel and Stepenny", "Sticheral of three months - March, April, May — in put and niz", "Sticheral in put and niz up to half a year", "Triodions in put and niz", "Demestvennik in all lines", "Holidays" and others [24, p. 129-130]. In July 1662 chanter of the $1^{\text {st }}$ stanitsa of the Tsar's choir Ivan Nikiforov was granted cloth for his writing the Theodor Stratilat Holiday [31, № 316, fol. 103]. The inventory of the Tsar's library also mentions some other chants written down by him [24, p. 129-131]. The same concerns the patriarchal singing diaki. Thus, in one of the documents it is stated, that the patriarch's singing diak Fyodor Konstantinov in June-August, 1667 used to buy paper for podiaki to write down chants [28, № 43, fol. 171, 200]. Apparently, that master himself was teaching young singers how to write chant books. Some of the manuscripts, written by himself, were stored in the Tsar's library: "Greek Easter Canon", "Holiday and canon of Assumption of the Mother of God", "2 doxasticons and a troparion, and a Greek contakion" and others [24, p. 129, 131]. There is plenty of such evidence. Only in the Inventory of the Tsar's library (1682), besides the ones mentioned above, there is a record of chanting manuscripts written by the following chanters: Yury Bukin, Semen Denisov, Bogdan Zlatoustovsky, Aleksey Nikiforov, Grigory Panfilov, Ivan Semenov and Yury Fedorov [24, p. 129-132]. All of them served in the Tsar's and the patriarchal choirs mainly in the first half of the $17^{\text {th }}$ century.

Singers also enriched their library by buying new chant books, though it happened quite rarely. The patriarch's singing diak Aleksey Sergeev, for example, on July, 3, 1685 was given 2,5 rubles for buying "the half-quire chant book, containing 70 "trezvons" (minor holidays) and doxasticons from Triodion - with a mark in the registry that the book was bought for church chanting and teaching young podiaki by order of the most holy patriarch" [28, № 115, fol. 144].

Closer to the last quarter of the $17^{\text {th }}$ century the singers of the main Russian choirs were directly engaged in writing chant books. It was connected first with the transition of the chanting repertoire to "istinnorechie" (pronunciation of words in church chant as they are pronounced in spoken language, as opposed to "razdelonorechie"), and then - with the creation of its variant in the five-line notation. That can be distinctly traced in the documents concerning the patriarchal choir. So, on July, 23, 1687 the podiak Nikita Georgiev was given out 1.1 rubles "to buy writing paper so that singing diaki and podiaki could write on it” [28, № 122 , fol. 365]. In the period of 1687-1689 Nikita Georgiev bought "good quality", "lined" paper, as well as miscellaneous supplies (extendable an oak desk, candlesticks, "iron pincers", cinnabar and others) for the "Chanters back chamber" in the court of the patriarch, where singing diaki and podiaki did their work [28, № 127, fol. 296, 336,373 ; № 129, fol. 361; etc.]. In the 1690 s the podiak Iosif Efremov bought paper "for music books"and lined it [28, № 134 , fol. 361 ; № 137 , fol. 163; etc.]. In the second half of the 1690-s music books of popular "Greek chant", "four-voice chant" and others were written by podiaki under the direction and supervision of Tikhon Semenov, "the teacher", who taught "minor podiaki to sing"; it was he, who gave out paper for "lining" and books for binding [28, № 160, fol. 168; № 170, fol. 162, 165 ; № 173 , fol. 161 etc.]. In $1701-1703$ "in various months and on various days" by order of the boyar I. A. Musin-Pushkin, probably for the court choirs, the singing diak Osip Novgorotsev rewrote 522 music note-books of chants, among which there were chants of "znamenny in four voices", patriarchal, Kiev, Greek variants; he got 23.6 rubles for his work and the paper [28, № 190, fol. 97-98].

Another type of work, not included in the scope of professional duties of the Tsar's and patriarch's chanters, but carried out by those masters, was connected with their non-singing activities. It was, mainly, a consequence of an insufficient differentiation and specialization of the state machinery and the various categories of service class people, ensuring its activities.

There exist records of granting the Tsar's singing diaki by "dannoe pristavstvo" over monastery and church lands dating back to the period of Ivan the Terrible's reign, including the grand-ducal period. "Danny pristav" was a sort of an intermediary in legal cases. The same duties at that time were performed by departmental diaki [ex.: 2, p. 39-40, 68-69]. In the beginning of the $17^{\text {th }}$ century singing diaki ceased to be assigned overseers since labour differentiation in serving people became more profound.

Duties of an overseer included considering the claims filed against monastery or cathedral elders, priests, servants, stewards, peasants or on the contrary those filed by them. Once or twice a year, according to the written requirements, claimants or respondents were forced to go to Moscow to the Tsar himself or to other people empowered by the Tsar for considering the case [1, v. 1, p. 282]. An exception was made for murder cases, which were examined beyond the common requirements. No one but for the "danny pristav" had the right to decide the cases. For performing the 


\section{Искусствоведение}

functions of overseers singers were given a special "reward from the treasury" [1, v. 1, p. $282 ; 47$, p. 157].

There exist some evidences of the activity of singing diaki as overseers. By the 1534 charter of Feodosia hermitage the Father Superior was given a right to pass judgment on monastery servants and peasants, and to "send" only the Tsar's singing diak Artemy Guriev, Protopopov's son, with regard to their cases [14, p. 296]. In September 1538 - February 1539 the murder case in Medynsky uyezd (district) was investigated by the singing diak-overseer Ivan Kostitsa. He was assigned to interrogate the peasants, neighbours of the murdered person and to find out if the suspects were on duty on the day of the murder, etc. [39, v. 2, p. 771-793]. On July, 25,1539 the Grand Duke Ivan granted the position of an overseer of the settlements and villages of the Moscow Assumption Cathedral to the krestovy diak Kryachok Trifonov, and when the diak "passed away", on April, 29,1542 he was replaced by already known to us Ivan Fomin, son of Kostitsa [47, p. 158]. By the Tsar's order of September, 20, 1551 the singing diaki Gavrila Afanasiev, Matvey Adamov, Dmitry Tsarev were assigned as overseers for the elders, servants and peasants of the Holy Trinity-St. Sergius monastery and small monasteries ascribed to it; on March, 15, 1556 when the latter two "were passed away", Tretyak Zverintsev replaced them $[1$, v. 1, 281-283]. At the request of the Father Superior of the Nativity of the Virgin Monastery in Bogolyubovo on July, 20, 1557 Ivan the Terrible assigned the singing diak Vasily Shish as an overseer of monastery servants and peasants [2, p. 221-222]. Tsar Fedor Ivanovich on September, 15, 1585 sent "his overseer", the singing diak Vasily Potapov, to the Kostroma Cathedral, and on September, 6, 1586 he confirmed the right of the Peshnoshsky monastery to have Sotnik Andreev as their overseer; the latter since January 1597 was already performing those functions in the lands of the St. Cyril of Beloozersk monastery [3, v. 1, p. 456; 15, p. 122-124; 19, p. 196 - 199]. And finally, there are scarce records of the assignment of the Tsar chanter as an overseer in the beginning of the $17^{\text {th }}$ century: by charters dated by December, 21, 1605 and July, 8, 1606 False Dmitry and Vasily Shuisky confirmed Bogdan Kipelov as an overseer of the Kirillo-Belozersky monastery [3, v. 1, p. 457 ; 37, fol. 228-230].

Similar to the above described government service was the service of "nedelschiki". Court chanters were to perform it as well. As opposed to an overseer, a "nedelschik" (the one who "did the weeks") was assigned for temporary missions on investigation and legal cases. According to the staff list dated by March, 20,1573 the duties of "nedelschiki" in the Tsar's choir were performed by Istoma, Postnik and Vasily Potapovs, Savluk Mikhailov and Tretyak Zverintsev (who in the 1550-s worked as an overseer) [4, p. 35-36].

The growth of the Russian departmental office administration resulted in engaging in its activity such literate persons, as singers of the patriarchal choir. At least, since Filaret Romanov's patriarchate they were assigned, for example, to process such cases, as "ordinand" cases. The point was that those who claimed for the position of deacons and priests had to file a petition addressing the patriarch, which had been written by "podiaki of minor stanitsas"; when the exaltation ceremony was over, the same podiaki made a corresponding record in the books of the patriarchal Treasury. The patriarchal singing diaki wrote to the ordinand a special "stavlenaya gramota" (ordinand deed), they took it to the patriarch for signature and to the Treasury for registration. The ordinand paid for the labour of the patriarchal singers employed in his affairs (including the diak, teaching the podiaki to conduct business), by depositing a certain amount of money in the Treasury [1, v. 4, p. 562-563]. In the documents of that department there are numerous records of monthly salaries of the ordinand payment to the patriarchal choir singers. Amounts of salaries depended on the number of ordinands in that or other month [28, № 1, fol. 187 , 280 etc.; № 3, fol. 196-210, 300 etc.]. But with the lapse of time this business initiated "the great red tape", which later drew a significant increase of money expenses. In 1675 patriarch Joachim decided to assure orderliness for the ordinand business conduct, by determining the amounts of fee, which was distributed among singing diaki, podiaki, and also given personally to the diak of the patriarchal choir Feodor Konstantinov "for teaching podiaki" [1, v. 4, p. 563].

Sometimes singers took part in drawing up or maintaining legal documents. In 1580 the Tsar's choir diak Fedosei Agaphonov witnessed the purchasing of the stremyanny's (groom, looking after the Tsar's horses) settlement and wasteland by the Tsar's krestovy diak Andrey Vereschevsky [35, fol. 1]. In December 1696 in the out-of-town patriarchal court "yardman Timoshkin's wife" was found dead in the house; among the expenses on investigation of the case "one grivna ( 0.1 rouble) to the singers for writing" was also mentioned [16, p. 329].

Being educated people, singers of the main Russian choirs were actively involved in writing books and manuscripts. The fact, that those masters were writing chant books and notebooks, was already mentioned above. Quite frequently they were also assigned to write non-chant books. For example, in 1654, while escorting Nikon "in a trip" to Holy Trinity-St. Sergius monastery, podiak Matvey Kuzmin was rewriting there “the Sluzhebnik (Missal) book of Serapion” [28, № 38, fol. 145]. In February and October 1671 podiak Pavel Ostafyev was rewarded with 1 rouble, and in April with food products (cereals, oat flour, malt) for writing the book "Matveevy pravila" ("Rules of Matthew"), and in October, together with him, podiak Pavel Ivanov was also rewarded for the same job [28, № 73 , fol. 257; № 75, fol. 283; 29, № 22, fol. 282]. In October 1680 podiaki Ivan Verigin and Alexander Isakov were given 1 rouble each for writing Ustav (the Charter) in Pravilnya (room used for writing) in the patriarchal court. For the work Aleksandr Isakov bought resin, ink nutgalls and a penknife himself [28, № 102, fol. 279, 422]. In 1693 this singer was mentioned as a retired podiak, who by order of the patriarch in Chudov monastery had been writing books with elder Evfimy (Euphemius). Apparently, Alexander became a scribe of the highest class. Since April 1693 he became one of the "patriarchal book scribes" with a salary of 6 roubles and stayed in that position till 1702 [28, № 147, fol. 111; № 152, fol. 21; № 179, fol. 21].

Apart from all the variety of functions performed by singers, they were also sometimes sent with certain 
missions to places inside the capital, or to distant regions of the country. For example, on 4 May 1656 the Tsar's singing diak Fedor Elizarov was told to transport to the Moscow residence of Suzdal archbishop an expensive "holiday hat for services with jewels and pearls", which was kept in the palace by the Tsar's decree of 1654 [30, № 5641, fol. 1]. More frequently such errands were much simpler. In July 1669 the Tsar's singing diak Savva Arkhipov was sent with two books of Apostle from the Tsar's Krestovaya chamber to Tainy prikaz (Department of Secret Affairs) for binding them into saffian and gilding the edges; in April 1670 the Tsar's choir diak Aleksey Fedotov carried Easter Triodion in red saffian with 'flowers' on the edges and the Lent Triodion to Sobor Pokrova "na Rvu" (St. Basil's Cathedral); in July 1670 to the same Cathedral and to some other Moscow churches Psalters and Heirmologions were sent out [39, v. 23, p. 28, 1648, 1651, 1652]. For the days of memorial in honour of the deceased Tsar's family members and other high-ranking officials, singing diaki had to deliver money to the churches of the capital, hire priests to hold the Mass. In March 1670 the Tsar's singing diaki Petr Pokrovets and Grigory Ivanov delivered money for the commemoration of Tsaritsa Maria Iliynichna and Tsareviches Semen and Aleksey to some churches of Kitai-gorod, Zamoskvorechie and of some other districts; in November 1675 the Tsar's singing diak Grigory Tikhonov was carrying out the same tasks in connection with the memorial days of boyar Morozov and his spouse, metropolitan Pavel Krutitsky who, while alive, was the head of the Pechatny Dvor (the Printing House) [39, v. 23, p. 1296, 1370, 1388, 1782]. By the Tsar's order in December 1672 and 1673 the patriarchal singing diak Fedor Konstantinov went to hire priests to hold liturgical services for the Tsaritsa and Tsareviches; in 1673-1674 the same task was given to the Tsar's singing diak Grigory Novgorodets, senior choir singer Pavel Ostafiev [39, v. 23, p. 101-102, 108, 176, 343].

Quite frequently singers were sent on long distant trips. In March 1622 the singing diaki of the Tsar's choir Ivan Ischeikin, Sergey Vasiliev and Vasily Kharitonov were rewarded with clothes "for the arrival from Siberian trip" - their return from Tobolsk, where they had traveled to the archbishop to teach his singers [31, № 207, fol. 283]. By August 1624 the Tsar's singing diak Samoilo Evtikheev returned to Moscow, he had also visited "the archbishop in Siberia where he was given his salary in cloth for 3 years" [30, № 979, fol. 1; 31, № 282, fol. 418-419]. In May 1663 the Tsar's diaki Osip Golchin and Andrey Fedorov together with Blagoveshchenskiy (Annunciation Church's) priest Aleksey were sent on some business "to the town of Arkhangelsk and Solovetsky monastery" with an instruction to let them pass "without any detention", and if they had goods with them, — to "collect" duties from them, like from merchants [30, № 8505, fol. 1]. In January 1665, the elder Antoniy (together with the singing diak Nikita Kazantsev) was sent from Moscow to Rozhdestvensky monastery, and there was an order to keep him there "with great care" [39, v. 23, p. 1144]. The singers were given weapons "for trips" from Oruzheiniy prikaz (Weaponry department). For example, in January 1687 the Tsar's diaki Zakhariy Lyubitsky and Vasily
Fominsky were given "a couple of pistoles" in iron holsters and two poleaxes; Dmitry Yanovskiy in January of the same year was given "two cavalry pistoles", a sabre in silver holder, and a "made in Turkey" bow [30, № 24933; № 24991; № 24999].

Finishing the review of non-singing activities of the Russian main choirs' singers, we shall mention that they were also engaged in a military sphere, which was completely different from their professional duties. The above-mentioned distribution of various weapon "for the diaki's trips" proves that singers, by all appearances, knew how to handle it very well. The preserved voivode staff list of Moscow, 1638, mentions arquebuses and spears (used in case it was necessary to defend the town) which were kept almost in every yard of the Tsar's or the patriarchal singing diak, as well as in the yards of departmental and serving class people of other "various ranks": on Mostovaya street, which led to the Vodyanye (Water) gates, in the yard of the Tsar's singing diak Roman Leontyev, where his "stepfather" Markel and a "man" named Romashko Osipov (apparently, he was a holop, feudally dependent person, bondman), Roman and Markel each had an arquebus, Romashko had a spear; on Znamenskaya street, stretching from Tresvyatskie to Arbatskie gates, there was a yard of the krestovy diak Vasily Semenov and his son Ivan, and each of them had an arquebus; in Bely Gorod (White stone town), by the church of Archangel Gabriel, there was a yard of the patriarchal podiak Afanasy Ignatiev, he also had an arquebus; on Nikitinskaya street by the church of Dionysius Areopagite the Tsaritsa's krestovy diak Gavriil Parfeniev lived with his son Arefiy and nephew Semen, and an arquebus was registered for each of them; etc. [38, p. 5, 22, 65-68, 108, 110, 128 etc.].

Most probably, just like other categories of serving people (for example, departmental diaki and podiaki) singing diaki sometimes took part in military shows and even exercises. The latter fact has numerous documented evidences. Thus, in October 1694 not far from Preobrazhenskoye an earth fortress was built and a siege plan was developed by Tsar Peter's order. Defenders of the fortress designated six streltsy regiments, a corps of all departmental diaki and podiaki, a corps of boyars, duma boyars, stolniks and others. This army also included horse cavalry of the Tsar's chanters. Their commander was an "old school" voivode I. I. Buturlin. But the new troops under the command of F. Y. Romodanovsky seized the fortress [7, p. 260261]. The above mentioned facts prove, that the duties of the professional singers in the Middle Ages Russia for a long time had the leftovers of the original main function of any serving person (as a vassal) - military one. The development of the state machinery and deepening of specialization in the sphere of various categories of serving people resulted in the elimination of functions alien to singers and their reduction to the basic one singing in the courts of the Tsar or the patriarch.

Dealing with the functions and the activity of the Tsar's and the patriarchal singing diaki, we did not touch upon such a special category of diaki, as krestovye diaki and a special subcategory of podiaki — podiakons.

Until the last quarter of the $17^{\text {th }}$ century singing, apparently, was not the main professional duty of the court krestovye diaki. In the Tsar's chambers, palaces 


\section{Искусствоведение}

or "rooms" of the Tsaritsas, Tsareviches and Tsarevnas their number in that time was not great (from 4 to 8-9). Without krestovye diaki the so-called "home divine services" could not be held. In December 1533 , having felt the vicinity of death, the Grand Duke Vasily Ivanovich said farewell to his wife and son, and "told his krestovy diak Danilka to sing the canon to the martyr Ekaterina and the canon to the departure of the soul"; on the day the Duke died in his "room" his krestovye diaki sang the Matins, "and hours, canons and funeral canons, and sang as they sang when he was alive" [45, p. 25,32$]$.

Here is the diaki's evidence of their duties. In March 1626 four krestovye diaki of Tsaritsa Evdokia Lukiyanovna filed a petition addressed her and Tsar Mikhail, which said, that as distinct from two krestovye priests, "who sing together with us in your, Tsaritsa's, chambers shifting by the week..., we sing in your, Tsaritsa's, chambers and in the church, and read the psalms, and read the canons in the church, and we four sing without shifts on kliros", just like "before we altogether sang in Tsar's, choir". Besides, the diaki reminded that previously, when they were serving to the Tsar, on some holidays and "the Tsar's name-day" they were assigned to "call the authorities", for what they were given damask for their "wives"; at the service of Tsaritsa that task "of calling the authorities" was not assigned to them anymore (in that petition they asked to resume giving out of damask) [30, № 1251, fol. 1].

As we can see, direct professional functions of krestovye diaki during the services were somewhat wider than those of the singing diaki. They had to not only sing, but read books as well, i.e. together with the krestovye priests they were responsible for holding divine services in the Tsar's chambers or court churches ${ }^{1}$. The latter circumstance gave rise to the increasing number of krestovye diaki in the second half of the $17^{\text {th }}$ century and to the formation of separate choirs for palace cathedrals, and later for the Tsar family members. The diaki took their name from the service "pri krestakh" (by the crosses) or "krestovaya sluzhba" (cross service).

But krestovye diaki not only had to participate in the divine services of court churches, they also had to prepare and get everything ready for them as well as to maintain the church equipment. The sources have brought us numerous examples of that fact. In October 1584 the Tsaritsa's krestovy diak Vasily Okhlebayev received holy water for the Bedroom of Tsaritsa Irina; on 13 December of the same year the Tsar's krestovy diak Nikon Semenov delivered holy water to the Bedroom of Tsar Fedor; on 4 October 1613 diak Ivan Titov was given holy water for the palace church of Ekaterina "in the Tsar's court"; on 9 September 1644 Afanasiy Fedulov was given holy water for the chambers of Tsarevnas [8, v. 1, p. 191, 194; 31, № 199, fol. 50; № 423, fol. 2 ; etc.].

The above mentioned Nikon Semenov was given two tablecloths in January 1587 for the consecration of Ekaterina's church, and in September 1624 Ivan Semionov delivered a veil, embroidered with pearls, into

${ }^{1}$ Singing in the Cathedrals in the first half of the 17 th century was especially rewarded. Tsaritsa Evdokia, for example, after "listening" to the Liturgy, granted money to the her krestovye diaki [31, № 632, fol. 228, 238, 240 etc.]. the Tsar's chambers; in February 1670 Petr Pokrovets bought 4 aspersoriums for the chambers, etc. [16, p. $1212 ; 31$, № 210, fol. 20; 39, v. 23, p. 1267]. The same diaki, apparently, were responsible for the availability of all the books for the court church services, were in charge of their safety. In November-December 1613 Ivan Semionov was given a "written book of Rule of Saint Apostles and Holy Fathers, a quire size, wrapped in leather", the "Written church Prologue (collection of lives of saints), a quire size, and written Menology, month January, half-quire"; on 9 January 1626 to the Tsar's court diak Vasily Semionov delivered a "printed Psalter"; and diak Avdey Vasiliev in July 1627 was given velvet to "bind" the Gospel for the chambers of Tsaritsa Irina [31, № 199, fol. 154, 159; № 211, fol. 69; № 212, fol. 235].

When necessary, diaki even bought books. Thus, in March 1670 Petr Pokrovets bought in Knizhny ryad (book market) 10 Octoechoses and 2 Apostles for the court church and the chambers [39, v. 23, p. 1644, 1647]. Krestovye diaki were also responsible for watching over icons. In January 1614 Bogdan Rudakov was given 9 "folding icons" and 11 "icons in gold and paint" for the new side altar of the church of the Nativity "in the Tsar's Court"; the same diak in July 1615 for the Tsar's "new chambers was given icons of various Saints painted with gold” [31, № 199, fol. 252; № 200, fol. 102; № 201, fol. 56; etc.]. Sometimes diaki were given cloth under the icons, but especially frequently they were given soap, brushes, "Greek" sponges to clean the icons and to wipe them [31, № 199, fol. 330; № 203, fol. 16; etc.).

On those especially revered Holidays and memorial days when the head of the state intended to attend the service at the Assumtion Cathedral, held by the patriarch himself, the Tsar's krestovye diaki appeared there beforehand. Some of their functions are mentioned in the Cathedral's "Chinovniks" of the 1620-30-s. Usually, having entered the Cathedral, the patriarch used to send one of his krestovye diaki "with the news" (most frequently — the first in the staff list or "the major" one) for the Tsar, and the Tsar's singing diaki sang Mnogoletie when the Tsar was entering the Cathedral $[46$, p. $64,104,185$ etc.]. Sometimes singing diaki were assigned to deliver the objects of worship that were kept in the Palace, like it was on the memorial day of the Moscow metropolitan Peter, when they were bringing in the "icon of Peter" to the Cathedral "from the room" of the Tsar [46, p. 203].

Apart from services the court krestovye diaki just like chanters participated in various rites, especially when those rites were connected with some events in the Tsar's family. For example, diaki "stayed in the chambers for the christening" of the newborn Tsareviches and Tsarevnas, for which they were given cloth and money ${ }^{2}$. At the funeral of Tsaritsa Maria Iliynichna in March 1669 together with the chanters krestovye diaki sang and read Psalter; in February 1670 they read Psalter for Tsarevich Aleksey "in his chambers", singing diaki in Arkhangelsky Sobor (Cathedral of the Archangel) [39, v. 23, p. 999, 1272-1273].

2 The "major" stanitsa's diak received cloth worth $8-10$ rubles and 5 rubles in money, the remaining diaks cloth in $3-5$ rubles and $3-4$ rubles [31, № 284 , fol. 252 ; № 286, fol. 7-8; № 288, fol. 617; etc.]. 
Quite frequently krestovye diaki along with the other court people had to escort those persons whom they served. In January 1635 the Tsar ordered his eight krestovye diaki to escort Tsaritsa Evdokia "in Trinity monastery winter tour", and to provide "four sledges and four horses" for that; it was told to provide krestovye diaki with sledges and horses, "as many as necessary", for the Tsar's trip to the Savvo-Storozhevsky monastery in January 1656 and to the Trinity-St. Sergius monastery in January 1659; in September 1662 Tsaritsa Maria and Tsarevnas were escorted to the Holy Trinity cloister by their diaki; etc. [30, № 2577, fol. 1, 14; № 5585, fol. 1; № 6302 , fol. 1 ; № 8174 , fol. 1 , 6 ; etc.]. In those trips the diaki kept performing their functions and arranged everything necessary beforehand. So, in July 1614 Bogdan Rudakov for "the trip to the Holy Trinity cloister" was given cloth "for the cushions into the box with icons" and holy water, and Ivan Semionov in the same period was given 20 gold coins [39, v. 9, p. 103, 313; 31, № 119 , fol. 41 ; etc.]. In the 1690 -s Tsarevna-ruler Sophia's sisters came to visit her in the Novo-Dyevitchi Convent where she was imprisoned. Sending krestovye diaki to the prisoner (the sisters had their own choir) was one of the manifestations of their love and care. In October 1698 Tsar Peter ordered to reduce the frequency of the sisters" visits, and not to "let the singers into the convent: the eldresses can sing well, too". The same had to be "requested humbly" from the aunt Tsarevna Tatiana [22, p. 268-269].

Like the chanters, krestovye diaki performed many duties, not connected with their direct professional activities. In the $16^{\text {th }}$ century they sometimes performed functions of overseers, like, for example, Kriachko Trifonov, who worked as an overseer of villages and settlements of the Assumption Cathedral at the end of the 1530's - beginning of the 1540's [47, p. 157-158]. In the $17^{\text {th }}$ century they were assigned to escort, among others, and meet the Russian “embassies” [30, № 6389, fol. 1-2]. They kept weapons in their yards for defence purposes [38, p. 22, 23, 32, 68]. In December 1665 Tsar Aleksey sent his krestovy diak Nikita Kazanets "with soldiers" to one of the first schismatics, antagonist of the church reform, deacon of the Annunciation Cathedral Feodor Ivanov, having ordered to "withdraw all books and writings from his house" and to deliver them to the Department of Secret Affairs, and to take Feodor to the town residence of metropolitan Pavel Krutitsky for expostulation [13, p. 316]. Krestovye diaki also performed various small assignments. Nikon Semenov on 3 August 1585 "delivered" the holy water to the Holy Trinity-St. Sergius; in the beginning of the 1600-s krestovye diaki usually were given "gold coins" from the Treasury for the Tsar, who, while traveling around the churches, was "putting" money to the icons; Ivan Semenov in January 1644 was assigned to deliver to Oruzheinaya palata (Armoury) 10 icons "painted with gold and paints"; Petr Pokrovets in August 1674 was assigned to deliver money to zolotopisets (gold painter) of the patriarchal court for painting of "a miniature" to one of the books $[8$, v. 1, p. $209 ; 39$, v. 9, p. 66, 71, 224 etc.; v. 23, p. 352].

Thus, the court singing diaki and krestovye diaki seem to have had similar activities in the $16-17^{\text {th }}$ centuries. In the staff lists they were put down next to each other, and took part in some events jointly. Music was of great importance in the activity of krestovye diaki (in the court of Ivan the Terrible one of the outstanding chanters served among them - Ivan Yuriev Nos). In the 1680 s the formation of separate choirs out of krestovye diaki was completed. Since that time even identical salary systems were established for krestovye and singing diaki.

A much more difficult task is to identify the functions of the patriarchal krestovye diaki. Their number in the court of the Patriarch was insignificant -1 or 2 (though, sometimes "for the cross service" individual singing diaki and podiaki were given additional payments), and only a few facts about their activity have reached us. Most probably, just like the court krestovye diaki in chambers, the patriarchal krestovye diaki were attached to the patriarchal "Keliya" (Cell) and the Krestovaya chamber for the "home" divine services, the patriarch's praying outside the church. There are several indirect facts and scarce information about it.

In 1651 the patriarchal krestovy diak Ivan Timofeev was binding two books of Octoechos for the library of the Krestovaya chamber, making clasps for three books, and also bought a printed "Canon to the Guardian Angel"; in July 1653 he "wrapped" two altar Gospels from the patriarch's Cell and the Krestovaya chamber in velvet, and in the same year he was binding and gilding the edges of five altar Gospels [28, № 28, fol. 311, 312; № 34, fol. 80 ; № 36, fol. 78]. Sometimes the patriarch assigned his krestovy diak to perform functions outside the court, which were similar to the functions of the senior choir singer (such position did not exist in the patriarchal choir). "Chinovnik" of the Assumtion Cathedral, for example, told: "The krestovy diak instructs to sing under the patriarch's order" [46, p. 177].

Quite difficult it is to identify all the peculiarities of such a category of the patriarchal singers, as podiakons as well. Before Nikon's patriarchate a stanitsa of "podiakons" was usually the 1st, or the "major" stanitsa of podiaki headed by a podiakon, who took some intermediate position between the diaki and the podiaki. Apparently, the singers of the podiakon stanitsa had to perform some functions, not performed by the other members of the patriarchal choir. With the exaltation of Patriarch Nikon all podiaki of that stanitsa began to be called "pod'yakony" (podiakons), their salaries were significantly increased, and then they began to be registered in the staff lists before the diaki. All these facts give evidence that the duties of those singers apparently changed in the course of time.

Let us dwell upon some specific records as far as the activities of podiakons are concerned. In 1656 together with podiaki in red and gold surplices they escorted the patriarch from the Krestovaya chamber to the services in the Assumption Cathedral and "all stanitsas sang various verses as they walked", and after the services also escorted the patriarch to the chamber [10, p. 14-16]. During "the Holy Passion Week" in 1693 podiakons, taking shifts with other singers, sang "Ispolaeti despota" in honour of the patriarch, read prokimena and the Apostle, and when the patriarch walked through the Tsar's doors podiakons walked in front of him with candles [10, p. 48 - 54]. Together with podiaki they dealt with the ordinand cases, and since September 1674 


\section{Искусствоведение}

the income they were getting from that activity became one of the basic forms of remuneration of labour, as by the patriarch's order it was forbidden to give salaries to the podiakons, they were paid money from the duties imposed on the Moscow ordinands [28, № 83, fol. 10]. In such a way, podiakons, who had previously been podiaki, were more similar to the podiaki according to the functions performed. They, undoubtedly, excelled in the art of chant. For example, in the second half of the 1680 -s podiakon Nikita Georgiev taught patriarchal singing diaki and podiaki to sing and wrote "chant books" with them [28, № 127, fol. 336, 386; № 129, fol. 366]

So, not only studied by us earlier legal position, established salaries and the system of payment, but also the Tsar's and patriarchal choirs singers' features of activities allow us to characterize them as court service class people of the Russian state of the $16^{\text {th }}-17^{\text {th }}$ centuries. Professional activity of masters of church singing art was considered as one of the types of state service. The directions of these activities have not been clearly defined and have often grown. This was due not only to the fact that the singers were literate, and sometimes had a high level of education. This can also be explained by the lack of clear differentiation of executive functions and duties in the developing state apparatus, which allowed in practice to use singers in solving various cases (clerical, judicial, military, etc.).

\section{References}

1. Acty istoricheskie, sobranii i izdannii Arkheograficheskoy Komissiey [Historical Acts collected and published by the Archaeographical Commission], v. 1. St. Petersburg, 1841 ; v. 3. St. Petersburg, 1841; v. 4. St. Petersburg, 1842; v. 5. St. Petersburg, 1842.

2. Acty, otnosyashiesya do grazhdanscoy raspravy drevney Rossii [Acts related to the civil law of Old Russia]. Publ. A. A. Fedotov-Chekhovsky, v. 1. Kiev, 1860.

3. Acty, sobranii v bibliotecakh $\mathrm{i}$ arkhivakh Rossiyskoy imperii Arkheograficheskoy Expeditsii Imperatorskoy Academii Nauk [Historical Acts Collected by the Archaeographical Expedition of the Academy of Sciences in the Libraries and Archives of the Russian Empire], v. 1. St. Petersburg, 1836.

4. Al'shits D. N. Novy dokument o ludyakh i prikazakh Oprichnogo dvora Ivana Groznogo posle 1572 g. [A new document on the people and departments of the Oprichny court of Ivan the Terrible after 1572]. Istoricheskiy arkhiv [Historical archive], v. 4, pp. 6-18.

5. Burilina E.L. Chin "Za prilivok o zdravii gosudarya": Istoriya formirovaniya $\mathrm{i}$ osobennosti bytovania [Ceremony "Za prilivok o zdravii gosudarya" (Health Cup) : History of formation and peculiarities of lifestyle]. Drevnerusskaya literatura. Istochnikovedenie [Old Russian literature: Sources ' study]. Leningrad, 1984, pp. $204-214$. № 425 .

6. GIM [State Historical Museum, Moscow]. Sinod.

7. Golikov I. I. Deyanya Petra Velikogo [Deeds of Peter the Great]. Moscow, 1788.

8. Dopolneniya k actam istoricheskim, sobrannii i izdannii Arkheograficheskoy Komissiey Imperatorskoy Academii Nauk [Additions to historical acts collected and published by the Archaeographical Commission.], v. 1. St. Petersburg, 1846; v. 2. St. Petersburg, 1846; v. 5. St. Petersburg, 1853; v. 6. St. Petersburg, 1857.

9. Dvortsovye razryady [Palace ranks], v. 1. St. Petersburg, 1850; v. 2. St. Petersburg, 1851.

10. Dubrovsky N. Patriarshie vykhody [The Patriarchs' Appearances in public]. Chtenija $v$ Obshestve Istorii $i$
Drevnostey Rossiyskirh pri Moskovskom universitete [Readings in the Imperial society of history and Russian antiquities at the Moscow University]. Moscow, 1869, book 2, section 5, pp. 7-64.

11. Zabelin I.E. Domashniy byt russkogo naroda v XVIXVII vekakh [Home life of the Russian people in the $16^{\text {th }}$ $17^{\text {th }}$ centuries], v. 2. Moscow, 1901.

12. Zabelin I.E. Domashniy byt russkikh Tsarei v XVIXVII vekakh [Domestic life of the Russian Tsars in the $16^{\text {th }}-17^{\text {th }}$ centuries $]$. Moscow, 1915.

13. Iz istorii russkogo raskola: diakon Feodor, ego sochineniya i uchenie [From the history of the Russian schism: Deacon Feodor, his writings and teaching]. Pravoslavnyi sobesednik [Orthodox interlocutor]. Kazan', 1859.

14. Istoriko-statesticheskoe opisanie tserkvey i monastirey Rjasanskoy eparkhii [Historical and statistical descriptions of churches and monasteries of Ryazan's eparchy]. Publ. I. Dobrolyubov, v. 4. Ryazan', 1891.

15. Kalaidovich K.F. Istoricheskoe i topograficheskoe opisanie muzhskogo obschezhitelnogo monastyria... na Peshnoshe [Historical and topographic description of a cenobitic monastery]. Moscow, 1837.

16. Materialy dlya istorii, arkheologii i statistiki goroda Moscvy / publ. I. E. Zabelin [Materials for the history, archaeology and statistics of Moscow], v. 1. Moscow, 1884.

17. Oleariy A. Opisanie puteshestviya v Moskoviyu i cherez Moskoviyu v Persiyu i obratno [Description of a trip to Muscovy and through Muscovy to Persia and back]. St. Petersburg, 1906.

18. Opyt trudov Vol'nogo Rossiyskogo Sobraniya pri Imperatorskom Moscowskom Universitete [Collection of works of Volnoe Rossijskoe Sobranie under the Emperor's University of Moscow], v. 2. Moscow, 1775.

19. Ostrovsky P. Istoricheskoe opisanie kostromskogo Uspenskogo sobora [Historical description of the Assumption Cathedral in Kostroma]. Moscow, 1855.

20. Parfentiev N.P. O deyatelnosti komissiy po ispravleniyu pevcheskikh knig v 17 veke [On the activity of the commissions for chant books editing in the $17^{\text {th }}$ century]. Archeograficheskiy ezhegodnik za 1984 [Archaeographical yearbook over 1984]. Moscow, 1986, pp. 128-139.

21. Parfentjev N. P. The singers of the central choirs of the Russian state of $16^{\text {th }}-17^{\text {th }}$ centuries as the "sluzhilye lyudi" of the tsar's and the patriarch's courts. Vestnik Uzhno-Ural'skogo gosudarstvennogo universiteta. Seriva: Sotsial'no-gumanitarnye nauki [Bulletin of the South Ural State University. Series: Social Sciences and the Humanities], 2019, v. 19, № 3, pp. 94-104.

22. Pis'ma i bumagi imperatora Petra Velikogo [Letters and papers of Emperor Peter the Great], v. 1, St. Petersburg, 1887.

23. Polnoe sobranie russkich letopisey [Full Collection of Russian Chronicles], v. 3. St. Petersburg, 1841; v. 12. Moscow, 1965.

24. Protopopov V.V. Notnaya biblioteka Tsarya Fedora Alekseevicha [Music library of Tsar Feodor Alekseevich]. Pamyatniki cultury. Novije otkrytija, 1976. [Cultural heritage. New discoveries. Scientific Publication, 1976]. Moscow, 1977, pp.129-130.

25. Razumovskiy D.V. Patriarshiye pevchie djyaki i podiyaki i gosudarevy pevchie diyaki [Patriarchal singing diaki and podiaki and the Tsar's singing diaki]. St. Petersburg, 1895.

26. RGADA. F. 156.

27. RGADA. F. 196. Inv. 1

28. RGADA. F. 235. Inv. 2

29. RGADA. F. 236. Inv. 1

30. RGADA. F. 396. Inv. 1

31. RGADA. F. 396. Inv. 2

32. RGADA. F. 1182. Inv. 1. № 69.

33. RGADA. F. 1192. Inv. 2

34. RGB. F. 37. № 364 . 
35. RGB. F. 303. Inv. 1. № 395.

36. RGB. F. 380. № 6.3.

37. RNB. St. Petersburg. D. A. № A.II / 47.

38. Rospisnoy spisok goroda Moscvy 1638 goda [Staff list of Moscow of 1638]. Publ. I. S. Belyaev. Trudy Moscovskogo otdela Russkogo voenno-istoricheskogo obshestva [Works of the Moscow department of the Russian military historical society], v. 1. Moscow, 1911.

39. Russkaya istoricheskaya biblioteca [State Public Historical Library of Russia], v. 2. St. Petersburg, 1875; v. 3. St. Petersburg, 1876; v. 9. St. Petersburg, 1884; v. 23. St. Petersburg, 1904.

40. Sbornic vipisoc iz archivnykh bumag o Petre Velikom [Collection of extracts from archival papers on Peter the Great]. Publ. G. V. Esipov, v. 1. Moscow, 1872.

41. Seredonin S. M. Izvestiya anglichan o Rossii XVI v. [News of the British about Russia in the $16^{\text {th }}$ century]. Chtenija $v$ Obshestve Istorii i Drevnostey Rossiyskikh pri Moskovskom universitete. [Readings in the Imperial society of history and Russian antiquities at the Moscow University], Moscow, 1884, book 4 , section 3, pp. 10-105. as the court service class people in $16^{\text {th }}-17^{\text {th }}$ centuries

42. Stroev P. M. Vykhody gosudarei tsarei (1632-1682) [The Tsars' Appearances in Public (1632-1682)]. Moscow, 1884.

43. Sukhotin L. M. Pervye mesyatsy tsarstvovaniya Mikhaila Fedorovicha [First months of Mikhail Feodorovich's reign]. Moscow, 1915.

44. Ustryalov N. Istoriya Tsarstvovaniya Petra Velikogo [History of Peter the Great's reign], v. 6. St. Petersburg, 1859.

45. Tsarstvennaya kniga, to est' Letopisets tsarstvovaniya Ioanna Vasiljevicha [The Tsar's book, i.e. The Chronicle of Tsar Ivan Vasilievich's reign]. St. Petersburg, 1769.

46. Chinovniki Moskovskogo Uspenskogo sobora i vykhody patriarkha Nikona [Service Books of the Moscow Assumtion Cathedral and Appearances of Patriarch Nikon]. Publ. A. P. Golubtsov. Moscow, 1908.

47. Shmelev G.N. Iz istorii moskovskogo uspenskogo sobora [From the history of the Moscow Assumption Cathedral]. Chtenija v Obshestve Istorii i Drevnostey Rossiyskikh pri Moskovskom universitete. [Readings in the Imperial society of history and Russian antiquities at the Moscow University]. Moscow, 1908, book 2, section 3, pp. 97-214.

\title{
ДЕЯТЕЛЬНОСТЬ ПЕВЧИХ ГЛАВНЫХ ХОРОВ РОССИЙСКОГО ГОСУДАРСТВА XVI-XVII вВ. КАК ПРИДВОРНЫХ СЛУЖИЛЫХ ЛЮДЕЙ
}

\author{
Н. П. Парфентьев \\ Южно-Уральский государственный университет, г. Челябинск, Российская Федерация
}

В Москве XVI-XVII вв. существовало два тесно связанных между собой центра профессионально-музыкального искусства. Это были хор при Царском дворе и хор при дворе Митрополита (с 1589 г. - Патриарха) Московского и всея Руси, которые объединяли лучшие музыкальные творческие силы страны. По мнению автора, изучение исторических данных о жизни и деятельности государевых и патриарших певчих свидетельствуют, что они входили в категорию придворных служилых людей. Направления этой деятельности не были четко определены и часто разрастались. Это объяснялось не только тем, что певцы владели грамотностью, а иногда и имели высокий уровень образованности, но также отсутствием четкой дифференциации служб в развивающемся государственном аппарате, что позволяло на практике использовать певцов при решении различных дел (делопроиводственных, судебных, военных и др.). Выводы базируются на основе анализа широкого круга разнообразных архивных документов и других источников. Полученные результаты позволяют уточнить социальный статус мастеров, которых нередко исследователи относят к духовному сословию.

Ключевые слова: государевы певчие дьяки, патриаршие певчие, придворные служилые люди, профессиональная деятельность.

\section{Литература и источники}

1. Акты исторические, собранные и изданные Археографической комиссией. — Т. 3. — СПб., 1841; Т. 4. — СПб., 1842; Т. 5. - СПб., 1842.

2. Акты, относящиеся до гражданской расправы древней России. - Т. 1. - Киев : Изд. А. Федотов-Чеховский, 1860.

3. Акты, собранные в библиотеках и архивах Российской империи Археографической экспедицией Императорской академии наук. - Т. 1. — СПб., 1836.

4. Альшиц, Д. Н. Новый документ о людях и приказах Опричного двора Ивана Грозного после 1572 г. / Д. Н. Альшиц // Исторический архив. - Т. 4. - С. 6-18.

5. Бурилина, Е. Л. Чин «За приливок о здравии государя»: Историй формирования и особенности бытования /

Е. Л. Бурилина // Древнерусская литература: Источниковедение. - Л., 1984. — С. 204-214.

6. ГИМ. Синод. № 425.

7. Голиков, И. И. Деяния Петра Великого / И. И. Голиков. - М., 1788.

8. Дополнения к Актам историческим, собранные и изданные Археографической комиссией Императорской академии наук. - Т. 1. - СПб., 1846; Т. 2. - СПб., 1846; Т. 5. - СПб., 1853; Т. 6. - СПб., 1857. 


\section{Искусствоведение}

9. Дворцовые разряды. - Т. 1. - СПб., 1850; Т. 2. - СПб., 1851.

10. Дубровский, Н. А. Патриаршие выходы / Н. А. Дубровский // ЧОИДР. - Кн. 2. - Разд. 5. - М., 1869. C. $7-64$.

11. Забелин, И. Е. Домашний быт русского народа в XVI-XVII вв. / И. Е. Забелин. — Т. 2. — М., 1901.

12. Забелин, И. Е. Домашний быт русских царей в XVI-XVII вв. / И. Е. Забелин. — М., 1915. 1859.

13. Из истории русского раскола: Дьякон Федор, его сочинения и учение // Православный собеседник. — Казань,

14. Историко-статистическое описание церквей и монастырей Рязанской епархии / сост. И. Добролюбов. - Т.4. Рязань, 1891.

15. Калайдович, К. Ф. Историческое и топографическое описание мужского общежительного монастыря... на Пешноше / К. Ф. Калайдович. - М., 1837.

16. Материалы для истории, археологии и статистики города Москвы / под ред. И. Забелина. — Т. 1. — М., 1884. 1906.

17. Олеарий, А. Описание путешествия в Московию и через Московию в Персию и обратно / А. Олеарий. - СПб.,

18. Опыт трудов Вольного российского собрания при имп. Московском университете. - Ч. 2. — М., 1775.

19. Островский, П. Историческое описание костромского Успенского собора / П. Островский. - М., 1855.

20. Парфентьев, Н. П. О деятельности комиссий по исправлению певческих книг в XVII в. / Н. П. Парфентьев // Археографический ежегодник за 1984 г. — М., 1986. - С. $128-139$.

21. Парфентьев, Н. П. Певчие главных хоров Российского государства XVI-XVII вв. как служилые люди государева и патриаршего дворов / Н. П. Парфентьев // Вестник Южно-Уральского государственного университета. Сер.: Социальногуманитарные науки, 2019. - Т. 19. - № 3. - С. 94-104.

22. Письма и бумаги императора Петра Великого. - Т. 1. - СПб., 1887.

23. Полное собрание русских летописей. - Т. 3. - СПб., 1841; Т. 12. — СПб., 1901.

24. Протопопов, В. В. Нотная библиотека царя Федора Алексеевича / В. В. Протопопов // Памятники культуры. Новые открытия. Ежегодник, 1976. - М. : Наука, 1977. — С. 129-130.

25. Разумовский, Д. В. Государевы певчие дьяки и патриаршие певчие дьяки подьяки / Д. В. Разумовский. — СПб., 1895.

26. РГАДА. Ф. 156.

27. РГАДА. Ф. 196. ОП. 1.

28. РГАДА. Ф. 235. Оп. 2.

29. РГАДА. Ф. 236, Оп. 1

30. РГАДА. Ф. 396. Оп. 1.

31. РГАДА. Ф. 396. ОП. 2.

32. РГАДА. Ф.1182. № 69.

33. РГАДА. Ф.1192. ОП. 2.

34. РГБ. Ф. 37. № 364.

35. РГБ. Ф. 303-1. № 395.

36. РГБ. Ф. 380 . № 6.3.

37. РНБ. СПб. Д.А. № А.II/47.

38. Росписной список города Москвы 1638 г. / Изд. И. С. Беляев // Труды Московского отдела Русского военноисторического общества. - Т. 1. - М., 1911. 1904.

39. Русская историческая библиотека. - Т. 2. - СПб., 1875; Т. 3. - СПб., 1876; Т. 9. - СПб., 1884; Т. 23. - СПб.,

40. Сборник выписок из архивных бумаг о Петре Великом / под ред. Г. В. Есипова. - Т. 1. - М., 1872.

41. Середонин, С. М. Известия англичан о России XVI в. / С. М. Середонин // ЧОИДР. — Кн. 4. — Разд. 3. - М., 1884. С. $10-105$.

42. Строев, П. М. Выходы государей царей... (1632-1682 гг.) / П. М. Строев. - М., 1844.

43. Сухотин, Л. М. Первые месяцы царствования Михаила Федоровича / Л. М. Сухотин. - М., 1915.

44. Устрялов, Н. История царствования Петра Великого / Н. Устрялов. - Т. 6. - СПб., 1859.

45. Царственная книга, то есть Летописец царствования царя Иоанна Васильевича. - СПб., 1769.

46. Чиновники Московского Успенского собора и выходы патриарха Никона - М. : Изд. А. П. Голубцов, 1908.

47. Шмелев, Г. Н. Из истории московского Успенского собора / Г. Н. Шмелев // ЧОИДР. — Кн. 2. - Разд. 3. - М., 1908. - C. $97-214$.

ПАРФЕНТЬЕВ Николай Павлович, заведующий кафедрой теологии, культуры и искусства, доктор исторических наук, доктор искусствоведения, профессор, заслуженный деятель науки Российской Федерации, Южно-Уральский государственный университет (Челябинск, Российская Федерация). E-mail: parfentevnp@susu.ru

Поступила в редакцию 2 сентября 2019 2.

\section{ОБРАЗЕЦ ЦИТИРОВАНИЯ}

Parfentiev N. P. Activity of the russian main choirs' singers as the court service class people in $16^{\text {th }}-17^{\text {th }}$ centuries // Вестник ЮУрГУ. Серия «Социально-гуманитарные науки». - 2019. - Т. 19, № 4. — С. 71-86. DOI: 10.14529 / ssh190410

\section{FOR CITATION}

Parfentiev N. P. Activity of the russian main choirs' singers as the court service class people in $16^{\text {th }}-17^{\text {th }}$ centuries. Bulletin of the South Ural State University. Ser. Social Sciences and the Gumanities. 2019, vol. 19, no. 4, pp. 71-86. DOI: $10.14529 / \mathrm{ssh} 190410$ 